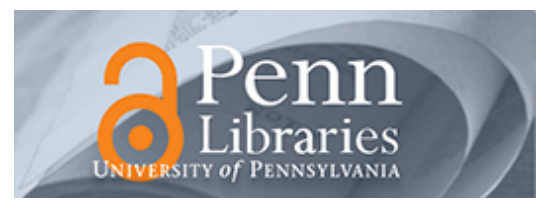

University of Pennsylvania

ScholarlyCommons

Management Papers

Wharton Faculty Research

$3-2013$

\title{
Divergent Reactions to Convergent Strategies: Investor Beliefs and Analyst Reactions During Technological Change
}

Mary J. Benner

Ram Ranganathan

University of Pennsylvania

Follow this and additional works at: https://repository.upenn.edu/mgmt_papers

Part of the Organizational Behavior and Theory Commons, and the Strategic Management Policy Commons

\section{Recommended Citation}

Benner, M. J., \& Ranganathan, R. (2013). Divergent Reactions to Convergent Strategies: Investor Beliefs and Analyst Reactions During Technological Change. Organization Science, 24 (2), 378-394.

http://dx.doi.org/10.1287/orsc. 1120.0755

This paper is posted at ScholarlyCommons. https://repository.upenn.edu/mgmt_papers/142

For more information, please contact repository@pobox.upenn.edu. 


\title{
Divergent Reactions to Convergent Strategies: Investor Beliefs and Analyst Reactions During Technological Change
}

\author{
Abstract \\ An important outcome of technological change is industry "convergence," as a new technology spurs \\ competition between established firms from different industries. We study the reactions of securities \\ analysts, as important sources of institutional pressures for firms, to the similar product/market \\ strategies undertaken by firms from different prior industries responding to industry convergence. Our \\ empirical setting is the convergence between the wireline telecommunications and cable television \\ industries in the period following the advent of voice over Internet protocol technology. Controlling for \\ firm financial performance and capabilities, we find that analysts were consistently more positive toward \\ the cable firms than toward the wireline telecom firms. Our findings further show that this divergence in \\ reactions arises from differences in existing investor expectations and preferences concerning how firms \\ create value; stocks owned by investors with a greater preference for growth receive more positive \\ reactions than those owned by investors with a greater preference for margins. However, this divergence \\ in reactions shrinks over time as convergence unfolds and as investors shift their shareholdings in \\ response to misalignment between their preferences and firms' strategic changes. Reactions from \\ analysts-reflecting inertial expectations of investors-may persist for a time despite changes to firms' \\ strategies, thus creating challenges for some firms in responding to technological change and industry \\ convergence while legitimating and enabling similar responses from their competitors.
}

\section{Keywords}

industry convergence, strategy, technological change, innovation, institutional theory, analysts, investor beliefs

\author{
Disciplines \\ Organizational Behavior and Theory | Strategic Management Policy
}

This journal article is available at ScholarlyCommons: https://repository.upenn.edu/mgmt_papers/142 
DIVERGENT REACTIONS TO CONVERGENT STRATEGIES: Investor beliefs and analyst reactions during technological change

\author{
Mary J. Benner \\ Strategic Management \& Organization \\ 3-422 Carlson School of Management \\ University of Minnesota \\ 321-19 ${ }^{\text {th }}$ Avenue South \\ Minneapolis, MN 55455 \\ mbenner@umn.edu \\ 612-626-6660 \\ Ram Ranganathan \\ Management Department \\ The Wharton School \\ 3620 Locust Walk \\ Philadelphia, PA 19104 \\ rram@wharton.upenn.edu
}

July 6, 2011

Revise and resubmit, Organization Science 


\title{
DIVERGENT REACTIONS TO CONVERGENT STRATEGIES: Investor beliefs and analyst reactions during technological change
}

\begin{abstract}
An important outcome of technological change is industry 'convergence,' as a new technology spurs competition between established firms from different industries. We study the reactions of securities analysts, as important sources of institutional pressures for firms, to the similar product/market strategies undertaken by firms from different prior industries responding to industry convergence. Our empirical setting is the convergence between the wireline telecommunications and cable television industries in the period following the advent of Voice over Internet Protocol (VoIP) technology. Controlling for firm financial performance and capabilities, we find that analysts were consistently more positive towards the cable firms than towards the wireline telecom firms. Our findings further show that this divergence in reactions arises from different pre-convergence investor expectations and preferences concerning how firms create value; stocks owned by investors with a greater preference for growth receive more positive reactions than those owned by investors with a greater preference for margins. However, this divergence in reactions shrinks over time as convergence unfolds and as investors shift their shareholdings in response to misalignment between their preferences and firms' updated strategies. These findings contribute to research on the challenges of technological change and industry convergence. Reactions from analysts - based on outdated investor expectations - may persist for a time in spite of changes to firms' strategies, thus creating challenges for some firms responding to technological change and convergence, while legitimating and enabling similar responses of their competitors.
\end{abstract}

Keywords: Convergence, technological change, analysts, investor beliefs 
Research since Schumpeter (1942) has focused on the importance of technological change for industry and firm evolution (e.g. Abernathy \& Utterback, 1978; Tushman \& Anderson, 1986; Henderson \& Clark, 1990). One important outcome of radical technological change for firms is industry 'convergence,' as a new technology allows established firms from different industries to compete in each others' product-markets (Greenstein and Khanna, 1997). Over the past few decades, firms in many industries have experienced convergence following technological advances in areas such as semiconductors, optics, and the Internet (Yoffie, 1997; cf. Srinivasan, Haunschild \& Grewal, 2007; Lee, 2007). For example, developments in the Internet and electronic paper technologies have facilitated industry convergence as firms offering similar electronic book products have entered from different prior industries: electronic book retailing (e.g. Amazon.com's Kindle), consumer electronics (e.g. Sony's eReader) and brick-and-mortar book retailing industries (e.g. Barnes and Noble's Nook).

A focus in previous research has been that the challenges and outcomes associated with technological change and industry convergence are due to factors internal to firms. Research has highlighted the importance of internal resources and capabilities in driving differences in firms' abilities to enter and succeed in new domains during a period of convergence (e.g. Klepper \& Simons, 2000; Helfat \& Lieberman, 2002; Mitchell, 1991). For example, Klepper \& Simons (2000) found that radio producers, firms with capabilities close to those required to produce televisions, were more likely to enter the TV industry, to enter early, and to survive. Similarly, the large body of research on the challenges of technological change for established firms has focused on internal factors, showing for example, that firms are constrained in their responses to new technologies by rigid organizational routines or structures (e.g. Leonard-Barton, 1992; Henderson \& Clark, 1990), the fear of cannibalizing the profits from the existing business (Reinganum, 1983; Henderson, 1993), organizational tendencies to exploit existing capabilities (e.g. March, 1991; Levinthal \& March, 1993; Benner \& Tushman, 2002), or managers’ outdated mindsets (Tripsas \& Gavetti, 2000).

But there has been little attention to the influences of external pressures as firms respond to industry convergence. In this paper, we take a first step to fill that empirical gap. Specifically, we follow 
a growing body of research that has considered analysts and investors as important sources of external pressures on firms (e.g. Zuckerman, 2000; Rao \& Sivakumar, 1999; Useem, 1996; Davis, 2005). We ask how analysts - reflecting investors' beliefs - react to firms' strategies during a period of industry convergence. Specifically, we study how analysts' reactions - and the pressures on firms from these important external stakeholders - systematically differ for firms, potentially constraining some firms responding to industry convergence, while enabling others pursuing similar strategies in the same domain. We build on cross-disciplinary research, including work in technological change, institutional theory, and finance and accounting to hypothesize that analysts' reactions to firms' strategies during convergence will systematically diverge to the extent that the firms are embedded in categories characterized by different notions of the sources of stock value (cf. Aghion and Stein, 2008). We argue that this divergence is associated with firms' prior industries, but that it arises specifically from differences in the composition of investors and corresponding differences in beliefs, expectations, and preferences about how firms do and should create value. We further hypothesize that although this divergence persists in both investor composition and corresponding analysts' reactions, it decreases over time as investors shift their stock market investments in response to firms' strategies that are misaligned with their expectations, and as uncertainty is reduced with the unfolding convergence.

Our empirical setting is the recent convergence between the wireline telecommunications (telecom) and the cable television (cable) industries triggered by a major technological change: the advent of voice over Internet protocol (VoIP) technology. VoIP technology allowed cable companies to offer telephone services and introduce a bundle of services that included internet, telephone, and television or video. The telecom firms similarly introduced bundles of the same three services. Thus, the advent of VoIP triggered convergence in these industries as firms began to compete in the same productmarket. We conduct a longitudinal panel data study of nine firms from 2001 to 2008, assessing analysts' reactions to the strategies and investments undertaken by these firms as industry convergence unfolded. Our statistical study design allows us to further control for observed and unobserved firm-specific and industry factors, including prior industry, financial performance, and firm capabilities. In addition, to 
supplement our quantitative study, we also read hundreds of pages of texts of the analysts' reports covering these nine firms to gain deeper insights into the unfolding process in our setting.

We find that to the extent a firm's stock is owned by investors with a preference for 'growth' stocks (generally a characteristic of cable firms at the outset of convergence), analysts' reactions are more positive, controlling for financial performance, capabilities, and other industry and firm factors. Conversely, analysts' reactions are more negative to the extent stocks are held by investors with preferences for 'margins.' We also find that the composition of investor preferences and expectations in each firm changes over time as more growth-oriented investors buy into telecom firms' stocks and fewer growth-oriented investors continue to hold cable firms' stocks. Thus, we find that as industry convergence unfolds, the characteristics of investors in firms and corresponding reactions to firms' strategies also converge.

These findings have important implications. We document systematic divergence in analysts' reactions that is highly correlated with a firm's prior industry, and is explained, not by differences in firmspecific capabilities or financial performance, but by differences in the pre-convergence expectations of investors holding a firm's stock. Although the composition of investors and their corresponding reactions to firms' strategies do eventually change over the study period, the relative inertia in investor characteristics creates important constraints on some firms while enabling others. Given evidence from research showing that pressures from analysts and investors affect firms' strategies (e.g. Zuckerman, 2000; Benner and Ranganathan, forthcoming; Bushee, 1998), these reactions likely affect firms' strategies and ability to change and adapt in response to important environmental changes. As differential pressures on firms translate into differences in levels of investment, speeds of adoption, degree of management attention (Ocasio, 1997), or commitment (Sull, Tedlow \& Rosenbloom, 1997), they may reinforce firm heterogeneity and further set apart 'winners' from 'losers' during periods of convergence (Collis et al, 1997).

In addition, our study contributes to research in several ways. First, we fill an empirical gap in technological change research by exploring the important but understudied external influences of analysts 
and investors on firms' responses. Past research has largely attributed the challenges of responding to technological change to internal organizational factors. Our study provides important insights into external factors that may reinforce these documented challenges. Finding that reactions and corresponding pressures from key stakeholders in firms' environments diverge systematically for specific groups of firms, independent of individual firm capabilities, resources, and financial performance, provides important insights into additional barriers as firms respond to changes in their environments. Our study also contributes to an empirical understanding of institutional change by highlighting categorical change over time in our setting. Recent work in institutional theory and institutional change has called for more research on how the power of institutions may increase or decrease over time (e.g. Dacin, Goodstein, and Scott, 2002). By using a novel measure of the composition and expectations of external stakeholders, we are able to document the shifts in firms' categories and corresponding changes in the pressures on firms.

\section{THEORY DEVELOPMENT}

\section{Securities analysts' recommendations and investor beliefs}

"Sell-side" securities analysts function as intermediaries in the stock market and issue periodic assessments and reports of firms' current performance as well as their future prospects (Schipper, 1991; Zuckerman, 1999; Rao \& Sivakumar, 1999; Benner, 2010). Analysts issue recommendations to 'buy,' 'hold,' or 'sell' firms' stocks. A growing body of research has documented the important effects of analysts' pressures on firms' strategies and actions (Benner and Ranganathan, forthcoming; Westphal and Graebner, 2010; Litov et al, 2009; Westphal and Clement, 2008; Zuckerman, 2000; Wiersema and Zhang, 2010).

Prior research suggests that analysts' recommendations are influenced by investors' expectations and beliefs, particularly those of large institutional investors such as mutual fund managers. These influences arise for several reasons. First, most sell-side securities analysts work for brokerage houses that derive trading revenues from large institutional investor clients (Jegadeesh et al, 2004; De Franco et al, 2007; Mola and Guidolin, 2009). Although the analyst's equity research department typically does not 
generate revenues (Jegadeesh et al, 2004), analysts' reports generated by the research department are used as marketing tools by the brokerage houses, raising the possibility that analysts cater to institutional investors to help brokerage houses obtain business. Second, analysts routinely communicate directly with institutional investors in less formal ways which provides them insights into investors' expectations and requirements (cf. De Franco et al, 2007). Finally, analysts are annually ranked in several prominent financial publications based on input from institutional investors (Boni and Womack, 2002; Institutional Investor Magazine, 2011) and their compensation and career opportunities are tied to these rankings. Consistent with these ideas, recent empirical evidence in finance shows that analyst optimism rises as investor sentiments climb and wanes as these sentiments fall, and this optimism is shown to be closely related to institutional investors (Qian, 2009).

\section{Investors' expectations - margins versus growth}

Recent research in finance proposes that investors' beliefs and expectations about appropriate firm activities arise from how they categorize firms' stocks, and in particular, the extent to which they consider firms to be 'growth' stocks versus 'margins' stocks (Aghion and Stein, 2008). Categorization of stocks as 'growth' or 'margins" is common both in academic research and in practice (e.g. Barberis and Shleifer, 2003; Jegadeesh et al, 2004; Benner, 2007; Aghion \& Stein, 2008). Investors' beliefs and expectations, in turn, drive how they value the stock and the specific metrics they use to assess performance (Aghion and Stein, 2008). Growth stocks are expected to pursue strategies that generate future revenue growth, while margins stocks are expected to pursue strategies focused on creating a stream of predictable earnings, cash flows, and dividends (Aghion and Stein, 2008). Not only are the stocks classified as 'growth' or 'margins,' but this categorization extends to the institutional investors such as mutual fund money managers who invest in the stocks, as funds are similarly classified as growth or value style investment funds (e.g. Barberis and Shleifer, 2003). 'Growth'-oriented investment funds invest in the stocks of firms expected to generate high future revenue growth whereas 'margin'-oriented

\footnotetext{
1 'Margins' stocks are also referred to as 'value' or 'income' stocks both in academic research and in practice
} 
investment funds generally invest in the stocks of firms expected to generate predictable current earnings and cash flows.

Aghion and Stein (2008) further propose that categorization of a firm's stock as growth or margins results from investors observing the types of strategies and investments the firm has undertaken historically. For instance, if a firm's activities have historically focused on cost-cutting and improving profit margins, its investors will tend to focus on current earnings and profitability metrics when evaluating the firm's performance while de-emphasizing other performance metrics such as revenue growth. In contrast, if a firm's activities have been exploratory for a time, such as investing in new technologies, over time its investors will begin to focus on growth-related metrics and may even ignore profitability and cost metrics when evaluating firm performance (e.g. Aghion and Stein, 2008). Moreover, these ideas suggest that the extent to which investors believe a firm to be a 'growth' or 'margins' stock affects investors' sentiments and analysts' reactions, independent of the firm's underlying capabilities.

\section{Divergent reactions during industry convergence}

Our interest is in how these categorizations affect analysts' recommendations toward firms during a period of technological change and industry convergence. Below we argue that analysts' reactions toward margin and growth stocks will systematically diverge, and will be more positive toward growth stocks and more negative toward margin stocks for three main reasons. First, an emerging stream of research in finance and accounting has begun to argue that securities analysts generally evaluate stocks that are categorized as 'growth' more favorably, even after accounting for the stock's performance and other observable fundamentals. This research has focused on the role of analysts' and brokerage firms' incentives (e.g. Das, Levine and Sivaramakrishnan, 1998; Jegadeesh et al, 2004; Baik, Farber and Petroni, 2009; Barniv et al, 2009; Mola and Guidolin, 2009; Ertimur et al, 2010; cf. Westphal and Clement, 2008). For instance, Jegadeesh et al (2004) argue that analysts prefer to cover growth stocks because 'growth' firms generate higher trading activity for brokerage firms and generally make for more attractive investment banking clients. Analysts thus tend to publicly endorse growth stocks by tilting attention and recommendations in their favor. Moreover, these preferences may cause analysts to not fully take into 
account the characteristics of these growth stocks to predict returns. Baik, Farber and Petroni (2009) show that analysts are more likely to make income-increasing and expense-reducing adjustments while projecting future valuation for growth stocks, when compared to margins stocks, and these excluded items are statistically significant in predicting future earnings for the growth stocks.

Thus, at the start of convergence, as firms from different industries respond to the same radical technological change with similar strategies, there is likely to be heterogeneity in the composition of existing investors, associated beliefs and expectations, and corresponding analyst recommendations regarding these firms. At the onset of convergence, some firms will be valued for 'growth' whereas others will be valued as 'margins' stocks, for their ability to deliver predictable earnings, and these differences are associated with prior industry. Despite convergence in industries and strategies, these preexisting categories likely spur different reactions from investors and analysts. For example, in the emerging electronic book industry, Internet retailing companies such as Amazon have traditionally been valued for revenue growth by investors (e.g. Aghion and Stein, 2008), whereas brick-and-mortar retailers such as Barnes and Noble have been valued for their margins. Even though these firms now compete in the same new domain with similar products, their existing composition of investors and associated expectations may spur different reactions as firms now pursue very similar strategies.

Moreover, evidence from prior research suggests that investor and analyst beliefs about a firm persist for a time despite changes in firms' strategies and environmental conditions. For instance, Beunza and Garud (2007) show that evaluative heuristics for Internet stocks remained static even as the underlying stock category underwent radical transformation. In the same empirical setting, Goldfarb, Kirsch and Miller (2007) suggest that there was a divergence between the beliefs of investors and venture capital firms. Venture capitalists continued to believe in outdated business models that advocated greater and faster growth, and this was misaligned with investors' preferences. Similarly, Tripsas (2009) suggests that the analysts covering a firm were slow to change how they categorized the firm despite the efforts a firm undertook to change its identity. Thus, investor beliefs and expectations are slow to change, further suggesting that despite underlying technological change and convergence in industry and 
strategies, investor expectations and analysts' reactions will, for a time, continue to reflect investors' preconvergence beliefs and expectations.

A second underlying reason for divergence in analysts' reactions is that instances of technological change and industry convergence trigger specific environmental conditions that favor firms categorized as growth stocks more than firms categorized as margin stocks. In particular, the technological change that enables convergence is characterized by high uncertainty as competing technological designs progressing at different rates create an 'era of ferment' (Tushman and Anderson, 1986). This uncertainty makes firms' performance less predictable and also makes it difficult to predict which firms will succeed (Collis et al, 1997). In the example of convergence in electronic books, it is difficult ex-ante to predict which firm(s) among the entrants (Sony, Amazon, Barnes and Noble, etc.) will emerge successful. Part of the uncertainty concerning the future value of firms entering this new domain is due to uncertainty in understanding whether and how quickly e-book readers and e-books will diffuse and achieve market adoption, questions that are unresolved in the short term. A market characterized by high uncertainty is more consistent with the expectations for firms valued as growth stocks, where investors focus on revenue growth with higher uncertainty and an expectation of greater value in the future, than with expectations for margin stocks, where the focus is on predictability and stability in earnings in the short term.

Finally, the strategic changes that are required to respond to technological change and compete in a converging industry often require increased investments to develop new knowledge and capabilities in the new technology (cf. Lavie, 2006; Agarwal and Helfat, 2009). The persistent expectations and beliefs of different investor types have implications for analysts' reactions specifically toward these increased investments. As we discuss above, the extent to which a firm's stock is held by investors preferring 'growth' versus 'margins' influences both the relevant metrics and heuristics investors attend to when evaluating the firm's strategic investments (e.g. Aghion and Stein, 2008; Bradshaw, 2004; Beunza and Garud, 2007), and how they evaluate the appropriateness of activities and strategies. Increases in strategic investments will be particularly misaligned for firms that are valued as 'margins' stocks, with expectations for stable, predictable earnings. As these firms increase investments, analysts will persist in 
emphasizing the 'margins' dimension, which makes the increased investment, and its negative effects on earnings, particularly salient in the short term. In addition, the high uncertainty in the future value of these investments during a period of technological flux is more consistent with the expectations for a growth stock than with the near-term stability in cash flows and earnings expected from a margin stock. As a result, investors and analysts will view increases in investments more unfavorably when evaluating margin-oriented stocks, causing analysts to downgrade stock recommendations or even drop coverage (Barber et al, 2001; Womack, 1996; Bjerring et al, 1983; cf. Zuckerman, 1999). In contrast, increases in investments undertaken by a firm that investors value for growth will be more favorably evaluated as such investments are more aligned with the investors' pre-existing beliefs about sources of value creation for those firms. Investors focused on future revenue growth rather than current margins already anticipate that a higher proportion of firm value will be derived from uncertain investments. Taken together, our arguments suggest that the reactions to firms held by investors interested in growth during a period of convergence will be more positive than toward firms held by margin-oriented investors, and further, that analysts' reactions will be even more negative toward increased investments by margin-oriented firms.

Hypothesis 1: During a period of industry convergence triggered by a major technological change, the more (less) growth-oriented the investors that own a firm's stock, the more positive (negative) securities analysts' reactions to the firm.

Hypothesis 2: During a period of industry convergence triggered by a major technological change, the more (less) growth-oriented the investors that own a firm's stock, the more (less) positive securities analysts' reactions to increases in that firm's strategic investments.

The relationships we proposed in Hypotheses 1 and 2 are further illustrated in text excerpts from the analysts' reports covering our firms during the study period. The texts provide qualitative evidence of both the divergence in reactions to similar strategies undertaken by cable and telecom firms ${ }^{2}$, as well as the analysts' focus on different metrics that underlie these reactions.

Analysts' statements from the reports on the cable firms highlight their generally positive reactions toward the cable firms' forays into bundled offerings combining Internet, telephone services,

\footnotetext{
${ }^{2}$ In the results section, we show that at the outset of convergence, cable firms' stocks were significantly more likely to be owned by investors interested in growth, while telecommunications firms' stocks were significantly more likely to be owned by investors interested in margins.
} 
and television or video (often called a 'triple play'). A Morgan Stanley report covering Comcast in July 2003 titled 'Looking into the Future' details four distinct future scenarios or outcomes to supplement the analysts' financials, including accelerating the rollout of these offerings. The first bundling event in 2004 similarly triggers headlines from analysts:

Since both the triple-play offer and the double-play telecom bundle offer include telephony. Cablevision is clearly prepared to provision a significant ramp in its telephony customer base. (Deutsche Bank, Cablevision, June 2004)

Cablevision's clear success rolling out and scaling VoIP telephony is evident as voice is the centerpiece....investors will now have the chance to see how successful an aggressive triple-play price point can be for cable operators (Deutsche Bank, Cablevision, June 2004)

Even before these efforts are fully underway, analysts discuss the potential for cable firms' phone service offerings.

We believe a rollout of VoIP (voice over IP) telephony to the entire footprint could be completed in the next two years ... we recognize that VoIP could drive telephony penetration higher and expand the footprint even more than originally expected. (Morgan Stanley, July 2003, Comcast)

In contrast, excerpts show that analysts are consistently more negative and pessimistic about similar bundled offerings from the telecom firms, and their comments focus on encouraging firms to retreat from participating in this new market. The analysts' comments also illustrate the focus on different metrics when evaluating the different firms. Below, they refer to cash flow and earnings (metrics associated with 'margin' stocks) when discussing telecom firms' bundled offerings. This contrasts with the focus in the excerpts from reports on the cable firms above on 'expanding the footprint' (i.e. increasing market share, which is a focus on growth metrics).

Three areas continue to concern us: ... Impact of building BLS' controlled video business, both from an operating, margin and capex [capital expenditure] perspective (Deutsche Bank report on Bellsouth, April 2005)

...we are concerned about the economics of the FiOS initiative [i.e. Verizon's investments in fiber to allow it to deliver video as part of its bundled triple offering], but a pull-back on this could make us more constructive on the stock... Curtailment of FiOS plans, more focus on cash generation, and potential divestitures could make us more positive (Morgan Stanley, multiple reports on Verizon between Oct 05 and Jan 06) 
These statements also further suggest that analysts are incorporating and reflecting investor sentiments in their recommendations. These texts and other business press articles (e.g. Mohammed, 2006) highlight

that at that time, investors are negative about Verizon's FiOS strategy:

Investors have been concerned over Verizon's FTTH [FiOS] strategy to accommodate high definition video delivery as well as extensive data bandwidth... (Deutsche Bank, report on Verizon, August 2006).

The investor and analyst negativity toward Verizon's efforts to respond to convergence suggested in the excerpts above is again illustrated below, in a statement repeated several times in analysts' reports. This suggests that analysts and investors would prefer to have Verizon curtail its investments in responding to the technological change and instead focus on short term cash flow (consistent with a 'margins' strategy):

We believe that if the FiOS project fails to achieve meaningful penetration rates, the rate of erosion of both revenue and EBITDA could be even steeper, and will confirm skeptics' claims that the company and its shareholders would have been better-off adopting a CZN-type structure (i.e. severely cutting back investments, maximizing short-to-medium term FCF [free cash flow] and... returning cash to shareholders) (Deutsche Bank, Verizon, Oct 2005)

In addition, in contrast to analysts' enthusiasm for the "triple play" offering in the reports on cable firms, analysts covering the telecom firms even question the market for the triple play offering:

...we are not yet convinced that consumers will demand the triple threat product... (Morgan Stanley, report on SBC, July 2003)

Finally, this divergence in reactions is starkly illustrated in a comparison of reports on Comcast and Verizon issued at the same time. Analysts question Verizon's FiOS rollout and recommend pulling back, even as they recognize that Verizon has superior capabilities, yet they encourage Comcast, even while noting that its strategy requires increased capital investments in the short term.

we are concerned about the economics of the FiOS initiative, but a pull-back on this could make us more constructive on the stock...Despite announcing its video packages for Keller...we believe it will be increasingly difficult for Verizon to continue with its fiber to the premises rollout. The architecture and capabilities are second to none, but the costs are high... (Morgan Stanley, Verizon, Sept. 2005)

An accelerated all-digital and VoIP rollout should increase capital expenditures in the near-term, but they should also generate stronger long-term growth. (Morgan Stanley, Comcast, October 2005)

\section{Towards convergence in investor beliefs and analyst reactions}

Our arguments in hypotheses 1 and 2 focus on how differences in investor composition give rise to divergent reactions to firms responding similarly to the same instance of industry convergence. 
However, since investors can diversify their stock portfolios, they do not have to continue to hold stock in a firm whose strategies and activities are increasingly misaligned with their investment preferences (cf. Amihud \& Lev, 1981). Over time, with increasing misalignment between investors' expectations and firms' strategies, investors are likely to shift their stockholdings, abandoning stocks that are most out of alignment with expectations. ${ }^{3}$ Specifically, investors are likely to move away from the stocks of 'margins' firms that are now investing to compete in an new and highly uncertain technological domain. Thus, as existing margins-oriented investors abandon stocks whose strategies no longer fit their investment preferences, the overall mix of investor characteristics in these firms changes, becoming less margins-oriented. This implies that as convergence unfolds, the strategic changes that ex ante 'margins' firms undertake to enter the new domain signal to investors and analysts that they are shifting toward investments in revenue growth and away from a focus on short-term earnings (cf. Aghion and Stein, 2008). At the same time, new investors with preferences for 'growth' stocks may now discover and invest in these firms whose strategies become increasingly aligned with their beliefs. Further, these investors will assess firm strategies and performance using metrics that are consistent with evaluating growth stocks. These ideas are consistent with the notion that investors' valuation models and metrics will, over time, take into consideration what they perceive to be a firm's current business strategy - i.e. the stock market's 'learning effect' (Aghion and Stein, 2008).

A comparable mechanism will operate for firms that are valued as 'growth' stocks preconvergence. Although the uncertain technological investments these firms make during the initial stages of convergence align with the growth expectations of investors (i.e. uncertain future payoffs and potentially high revenue growth), the reduction in uncertainty in the later part of convergence will have a contrasting effect. As the post-convergence dominant design and winning business models begin to emerge, the projected future payoffs to firms' technological bets also begin to materialize in the firms'

\footnotetext{
${ }^{3}$ Further supporting our arguments about inertia in categories in hypothesis 1 , this process can be delayed, particularly for large institutional investors, as they take an interventionist approach and try to encourage changes in a firm's actions prior to selling their stock. Because such investors may hold a large percentage of a firm's stock, they face incentives to intervene to change a firm's strategies rather than immediately follow the "Wall Street rule" by selling their shares (cf. Kahn and Winton, 1998).
} 
current earnings. Additionally, with the emerging dominant design, these firms will tend to shift focus, in part, away from the exploratory activities of the earlier phase of convergence and era of ferment, toward exploitative activities in order to cut costs and improve efficiency and productivity (Tushman and Anderson, 1986; Abernathy and Utterback, 1978; cf. Benner and Tushman, 2002). As investors interpret and assess these shifts in firms' strategies and performance, those interested primarily in growth in future revenue are likely to move their investments out whereas new investors with a preference for the characteristics of margin stocks may choose to buy into these firms, again shifting the underlying investor orientation, in this case, away from 'growth' and towards 'margins.' Thus:

Hypothesis 3: As industry convergence unfolds, there will be increasing convergence in the composition of investors in firms competing with similar strategies in the converged industry.

These dynamics are also illustrated clearly in the texts of analysts' reports. Below, we show an excerpt from an analyst's report late in our study period. The analyst recommends a 'buy' on Qwest, a telecommunications company, with the rationale that the investors who were only interested in short term dividend payouts have sold off their shares, giving the company more leeway for long-term strategies as they are now held by investors interested in growth stocks:

Buy... many investors who were focused solely on the potential for a dividend that might result in a near-term lift in the share price, and not on what would be best for the company in the long-term. We believe this became apparent when the company announced...that it would invest $\$ 200$ million ...to build out fiber... and the stock subsequently sold off sharply. With this segment of Qwest's investor base now largely gone.... the new management team has additional freedom to explore opportunities to enhance shareholder value over the longer term that are not necessarily immediately accretive to free cash flow...(Deutsche Bank analyst report, Qwest, February 2008)

This text also illustrates that analysts' recommendations anticipate and reflect the expectations and behaviors of investors. Moreover, it is apparent that at a point late in the convergence period, analysts are beginning to shift to views of Qwest as a 'growth' stock, and have correspondingly become positive toward increases in investments that have uncertain future value. This contrasts sharply with their negative reactions to Verizon's similar increases in investments four years earlier.

As investors shift their investments in response to the misalignment precipitated by convergence and the overall investor orientation of the firms changes, these new expectations will be further reflected in 
analysts' reactions to firms' strategies and investments (e.g. Mola and Guidolin, 2009). As growthoriented investors begin to move away from firms that were ex-ante valued for 'growth', and as marginsoriented investors begin to buy these firms' stocks, analysts will also reduce their emphasis on the associated growth dimensions and increase their emphasis on margins dimensions when evaluating these firms. Moreover, as the earnings for such firms becomes more certain and predictable, analysts' preferential reactions associated with growth category firms (outlined in our arguments for Hypothesis 1), are less likely to boost the recommendations that these firms receive. Similarly, as the investor mix underlying the ex-ante 'margins' firms shifts towards growth, analysts' views will reflect the preferences and beliefs of the new 'growth' oriented investors when making recommendations. Thus, analysts will react less negatively to reductions in profit margins and earnings and will focus more on revenue growth when evaluating the strategies of such firms. In sum, we hypothesize:

Hypothesis 4: As industry convergence unfolds, there will be increasing convergence in analysts' recommendations for firms competing with similar strategies in the converged industry.

\section{EMPIRICAL SETTING, MEASURES, AND METHODS}

\section{Convergence in the wireline telecommunications and cable television industries}

Our setting is convergence between the wireline telecommunications and cable television industries (cf. Lee, 2007). The industry change was enabled by Voice-Over-Internet-Protocol (VoIP) technology that was first commercialized in 2002 , marked by the entry of Vonage. ${ }^{4}$ VoIP is a radical technological change that allows phone calls to be transmitted digitally over any transmission network using the Internet. Although early VoIP deployments were plagued with quality problems, continued improvements in the performance and price of the new technology led to rapid commercialization. In addition, VoIP technology provided a way for cable television firms to offer telephone services. Cable firms subsequently offered bundles of services (sometimes called a 'triple play'), that included telephone, video, and high-speed Internet. The telecommunications firms responded, both by offering standalone VoIP telephony products on existing copper-based wireline networks, as well as offering similar bundles

\footnotetext{
${ }^{4}$ Vonage, a startup established in 2001 is widely regarded as the commercial pioneer of VoIP
} 
of internet, video and telephone services, often on upgraded fiber-optic networks. Thus, while cable firms entered the telecommunications industry with telephone services, telecommunications firms entered the cable industry with video services, marking convergence between the two. Table 1 and Table 2 provide a summary of product introduction events ${ }^{5}$ corresponding to the industry convergence time frame.

Our study includes five telecommunications firms: Verizon Communications, Qwest, Bellsouth ${ }^{6}$, SBC Communications, AT\& ${ }^{7}$, and four cable firms: Comcast Corporation, Cablevision Systems, Charter Communications and Time Warner Cable. ${ }^{8}$ Our study period is from the first quarter of 2001 to the second quarter of 2008 .

\section{Measures}

\section{Dependent and explanatory variables}

In Hypotheses 1 and 2, we predict analysts' reactions toward converging strategies will diverge as a result of differences in expectations of investors for different categories of stocks. We measure analysts' reactions using the Mean analyst recommendation value from the I/B/E/S (Institutional Brokers Estimate System) (e.g. Jensen, 2006) summary file, which averages recommendations across all analysts that track a firm, every quarter. The variable is coded as: 1=Strong Buy, 2=Buy, 3=Hold, 4=Underperform, 5=Sell. Thus, higher values of this variable indicate more negative reactions.

Our explanatory variable for Hypothesis 1 is a measure of expectations of the investors holding a firm's stock, and specifically the extent to which they are growth- versus margins-oriented. We use data on mutual fund classification codes (Lipper codes) from the Center for Research in Security Prices (CRSP) Survivor-Bias-Free US Mutual Fund database to create a novel measure of the beliefs and expectations of investors holding a particular stock. Lipper, recognized as one of the industry standards in mutual fund classification (cf. Lounsbury and Rao, 2004), categorizes mutual funds according to

\footnotetext{
${ }^{5}$ Data obtained from Lexis/Nexis and technology specific websites (e.g. dslreports.com telephonyonline.com, informationweek.com)

${ }^{6}$ AT\&T acquired Bellsouth on March $5^{\text {th }}, 2006$. Analyst reports covering Bellsouth are discontinued after 2005.

${ }^{7}$ SBC Communications acquired AT\&T in late 2005, creating a new company called AT\&T Inc.

${ }^{8}$ Two other cable firms could not be included in the study: Adelphia filed for bankruptcy in 2002, and Cox Communications is privately owned and therefore not covered by analysts.
} 
investment style and objectives. In addition, we collected data from the Thomson-Reuters Mutual Fund Holdings Database, which tracks the volume of shareholdings, by firm and by fund, for this subset of mutual funds that own our firms' stocks. Using mutual fund investment objectives and shareholdings data, we computed a unique weighted measure of investor beliefs for each firm. To create our Investor profile measure, we first calculate a mutual fund profile for every mutual fund that invests in firms in our sample using the Lipper classification code field in the CRSP data (Thomson-Reuters, 2008). "Growth" "core" and "value" constitute three distinct categories of investment objectives among equity funds. "Value" (i.e. "margin," or "income") funds are those that emphasize steady current income flow (margins-orientation) and "growth" funds are those that have a future capital appreciation objective (growth-orientation), with "core" constituting an intermediate style. In addition to equity mutual funds, mixed funds that invest in both debt (bonds) and equity also owned stock in our firms - these funds have a greater current income orientation (higher margin orientation) compared to equity funds. We transform these mutual fund investment styles to mutual fund profile scores as follows: we first assigned a value of 1 for 'mixed' funds that have a greater focus on bonds (fixed income) than equity and a value of 2 for 'mixed' funds that have a greater focus on equity than bonds (greater growth-orientation). ${ }^{9}$ Among equity funds, we assign values of 3, 4, and 5 to value funds, core funds and growth funds respectively. Thus, our mutual fund profile scale runs from 1 (least oriented towards growth) to 5 (most oriented towards growth). ${ }^{10}$ Finally, we compute a weighted-average value for the Investor profile of every firm in our sample as follows:

Investor_Profile $_{\mathrm{i}, \mathrm{j}}=\sum_{\mathrm{k}}\left\{\right.$ Mutual_Fund_Profile $_{\mathrm{k}} *\left(\right.$ Shares_Owned $_{\mathrm{i}, \mathrm{j}, \mathrm{k}} /\left(\sum_{\mathrm{k}}\right.$ Shares_Owned $\left.\left.\left._{\mathrm{i}, \mathrm{j}, \mathrm{k}}\right)\right)\right\}$ Where: $\mathrm{i}=$ Firm, $\mathrm{j}=$ Period, $\mathrm{k}=$ Mutual Fund, and, Mutual_Fund_Profile ${ }_{\mathrm{k}}$ : Is measured on a scale from 1 (focus on income) versus 5 (focus on growth) for fund ' $k$ '. This remains constant for a fund across periods and firms. Shares_Owned $\mathrm{i}_{\mathrm{i}, \mathrm{k}, \mathrm{k}}$ : Is the number of shares owned by fund ' $\mathrm{k}$ ' of firm ' $i$ ' in period ' $\mathrm{j}$ '.

The weight used for a mutual fund ' $k$ ' is the proportion of firm ' $i$ ' equity held by the fund divided by the total equity of that firm held by all mutual funds in a period 'j'. The resulting Investor profile variable

\footnotetext{
${ }^{9}$ This was determined from both the description of the Lipper classification for the mutual fund and the more detailed fund objective field from CRSP/Reuters.

${ }^{10}$ For the small proportion of funds that did not fit into this coding scheme (e.g. Global Science and Technology funds, specialty funds etc.), we assigned a value based on our assessment of the fund objective.
} 
takes on values between 1 and 5 with higher values indicating greater growth-orientation of the investors that own the firm's stock. Thus, given the scaling of Mean analyst recommendations (lower values indicate more positive reactions), Hypothesis 1 predicts a negative coefficient for Investor profile.

Our explanatory variable for Hypothesis 2 is the interaction between our Investor profile measure and the firm's strategic investments during convergence to test whether analysts' reactions are more negative toward increasing investments by margin-oriented firms than growth-oriented firms. Following prior research, we measure a firm's strategic investments using the logged value of Capital expenditure (e.g. Maritan, 2001; Kotha and Nair, 1995; Litov, Moreton, and Zenger, 2009; Benner and Ranganathan, forthcoming). Although it is not possible to obtain a breakdown of firms' capital expenditures to assess the nature of the investments, our reading of hundreds of pages of analysts' reports (also illustrated in the excerpts provided above) suggests that firms from both industries in this study were increasing capital investments specifically to participate in the new "triple-play" market, and analysts were aware of - and reacting to - these increased expenditures. ${ }^{11}$ More specifically, the increases in capital expenditures during this time were likely to be undertaken as firms developed and introduced bundled offerings in the converging industry. ${ }^{12}$ We predict a negative coefficient on the interaction term, indicating that analysts are more positive toward increased investments for growth stocks.

In Hypothesis 3 and 4, we predict that divergence in investor expectations and analysts' reactions will shrink as industry convergence unfolds. To test Hypothesis 3, we assess whether there is a shift in the investors holding firms' stocks over our study period. Thus, we test whether stocks that were held by more (less) growth-oriented investors in the early part of convergence (early in our study period) are held by less (more) growth-oriented investors during the later stages of convergence later in our study period. We use Investor profile as the dependent variable to test Hypothesis 3, and our explanatory variable is an interaction between Time period and Initial investor profile. Initial investor profile measures the investor

\footnotetext{
${ }^{11}$ Importantly, there is no evidence from analysts' reports or the texts of conference calls or meetings with analysts during this period that there were increases in investments aimed at improving the 'old' copper wireline technology. ${ }^{12}$ This is particularly relevant in our models with firm fixed effects, described below, where the statistical variation used in the models is within-firm. Thus, it is specifically the increases in capital expenditures over time driving any results, and differences in levels of capital expenditures across firms.
} 
orientation immediately prior to the onset of convergence and is computed using the same weighted average formula detailed above. Time period measures the number of periods elapsed following the start of convergence ${ }^{13}$. Greater values for Time period correspond to the later phases of convergence. We predict a negative coefficient for this interaction term - i.e. as convergence unfolds (higher values of Time period), firms that had more (less) growth-oriented investors at the beginning of convergence (higher values of Initial investor profile) will have less (more) growth-oriented investors as time elapses. This corresponds to the shift in the investor mix that we discuss under the logic for Hypothesis 3.

In Hypothesis 4, we predict that, as a result of the changes in investor composition, analysts' recommendations will also converge over time. In part, support for this hypothesis is provided by finding support for Hypothesis 1, since that hypothesis predicts that an increasing composition of growth investors will spur more positive analysts' reactions. However, we supplement that test by also testing whether it is specifically the firms with stocks held by more (less) growth-oriented investors during the initial stages of convergence that receive more negative (positive) reactions during the later stages of convergence), showing that there is an underlying shift in reactions to firms between the outset and end of the convergence period.

Our dependent variable to test Hypothesis 4 is Mean analyst recommendation. Our explanatory variable is again an interaction term between time period and the investor profile prior to convergence (Time period $X$ Initial investor profile), in this case to assess convergence in analysts' recommendations at a later time in our study period. Given the scaling of Mean analyst recommendation, we predict a positive coefficient for this interaction term - i.e. as convergence unfolds (higher values of Time period) the analysts' recommendations for firms that had more growth-oriented investors at the beginning of convergence (higher values of Initial investor profile) will become more negative, and more positive toward the firms that had fewer growth-oriented investors at the start of convergence.

\section{Control variables}

\footnotetext{
${ }^{13}$ Following STATA convention for date format, we measure time period as the number of quarters elapsed since January $1^{\text {st }}, 1960$. Thus, our observations begin at time period=164 and end at time period=195
} 
We control for inter-industry differences that might influence our dependent variables beyond the mechanisms we hypothesize, by including an Industry dummy variable, which we set equal to 1 for all firms in the cable industry and equal to 0 for all firms in the wireline telecom industry. We also control for financial and stock price performance using data collected from Compustat and CRSP. We control for both a firm's stock market performance and its accounting performance in the previous period using Share price and Return on assets. We also control for a firm's financial resources (leverage) using a measure of Debt ratio (cf. Miller and Bromiley, 1990). We use the log of the firm's Assets to control for firm size. A firm's asset base is a measure of its diversification which may be an indicator of future firm performance and thus correlated with our dependent variables (Berger and Ofek, 1995).

Finally, we use measures of Cumulative patent count and Cumulative patent forward citation count as measures of a firm's technological capabilities and technological knowledge (e.g. Ahuja and Katila, 2001; Stuart and Podolny, 1996). We collected these data using the NBER patent database (Hall, Jaffe and Trajtenberg, 2005). By controlling explicitly for firms' technological capabilities, we address a concern that analysts may consider the technological potential of a firm in their recommendations, as firms often "know more than they make" (Brusoni, Prencipe, \& Pavitt, 2001). ${ }^{14}$ Our sample size was limited by the availability of patent data which is available in the NBER database only through 2006, so we also tested our hypotheses on a larger sample that excludes the patent variables. Our results were similar.

In our models to test Hypothesis 3, we additionally control for Mean analyst recommendation from the prior time period to account for effects that analyst recommendations may have on investor behavior. Finally, we use time period controls in all our regressions to account for unobserved period effects. Table 3 provides the sample statistics and correlations for all the variables.

\section{Method}

\footnotetext{
${ }^{14}$ We used the two relevant technological categories - Computers and Communications, Electrical and Electronics to filter the patents.
} 
Our research design is at the level of firm-quarter. We have an unbalanced panel as one firm (Time Warner) enters the panel only in 2002 (this is the year when analysts start covering it), and two other firms (Bell South and SBS) merge with AT\&T in 2006-2007. To alleviate simultaneity and reverse causality concerns, we lag all explanatory and control variables by one time period in each of our regression models. We estimate the coefficients in STATA using Generalized Least Squares (the xtreg command). For each hypothesis, we obtain the estimates by first assuming that the unobserved firm effects are randomly distributed (random-effects models) and then test the robustness of our results to within-firm changes by changing to a firm fixed effects assumption. The fixed effects models utilize within-firm variation, controlling for unobserved heterogeneity across firms that might confound our results. As we discuss below, our results are robust to both specifications.

\section{RESULTS}

We first conduct a t-test comparing Mean analyst recommendation and Investor profile between cable and telecom firms to assess differences across industry. As shown in Table 4, we find a significant difference $(\mathrm{p}<.01)$ between the analysts' recommendations for telecom firms and cable firms, with the cable firms receiving more positive (lower in value) analyst recommendations by 0.34 (a difference of about $9 \%)$. There is also a significant difference $(\mathrm{p}<.01)$ in the investor profile of the telecom firms and cable firms at the beginning of the convergence period - by this measure, the cable firms are owned by more growth-oriented investors than the telecom firms by 0.77 (a difference of about 20\%). This initial test provides preliminary support for Hypothesis 1 and for our insights from the analyst report texts about the divergence in analysts' reactions for firms in the two different industries.

Table 5 shows the results of our regression models to test Hypotheses 1 and 2. Models 1-4 include random effects while Models 5-8 include firm fixed effects. Models 1 and 5 are controls-only models and in Models 2 and 6, we add the Investor profile variable. The coefficient for this variable is negative and highly significant in both random and fixed effects models, thus providing support for Hypothesis 1, that firms that were owned by more growth-oriented investors received more favorable ratings from analysts. An increase of one unit in the investor profile is associated with approximately a 
one standard deviation improvement in analyst ratings. In Models 3 and 7 we add the interaction term Investor profile $X(\log )$ Capital expenditure. The coefficient for this term is also negative and highly significant in both random and fixed effects models, providing strong support for Hypothesis 2, that firms owned by more growth-oriented investors received higher analyst ratings when they increased their strategic investments during convergence. Models 4 and 8 are identical to Models 3 and 7 except that we exclude the patent variables to increase the number of observations. Hypotheses 1 and 2 continue to be strongly supported in these models.

Table 6A shows the results of our regression models to test Hypothesis 3. Models 9-11 are random effects models whereas Models 12-14 are fixed effects models. Models 9 and 12 are controls-only models and in Models 10 and 13, we add the main explanatory variable, the interaction term Time period $x$ Initial investor profile. The coefficient for this variable is negative and highly significant in both random and fixed effects models, thus supporting our argument in Hypothesis 3 that as convergence unfolded, growth oriented investors tended to invest in firms that pre-convergence had more marginsoriented investors, and margins-oriented investors increased investments in firms that had more growthoriented investors pre-convergence. Models 11 and 14 are identical to Models 10 and 13 except that we exclude the patent variables to increase the number of observations. Hypothesis 3 continues to be strongly supported in these models.

Table 7 shows the results of our regression models to test Hypothesis 4. Models 21-23 are random effects models whereas Models 24-26 are fixed effects models. Models 21 and 24 are controlsonly models and in Models 22 and 25, we add the main predictor, the interaction term Time period X Initial investor profile. The coefficient for this variable is positive and highly significant in both random and fixed effects models, thus supporting our argument in Hypothesis 4 that as convergence unfolded, analysts' recommendations tended to also converge. Over time as convergence unfolded, analysts' recommendations became more negative for firms that had growth-oriented investors pre-convergence, and more positive for firms that had margins-oriented investors pre-convergence. Models 23 and 26 are 
identical to Models 22 and 25 except that we exclude the patent variables. Hypothesis 4 continues to be strongly supported in these models.

\section{Robustness Checks}

By replicating our regressions using firm fixed-effects models, our analysis controls for unobserved fixed characteristics of firms that may be causing the variation we observe in analysts' reactions or in investor behavior. Concerns of simultaneity or reverse causality are also addressed by lagging of the predictor and control variables. Beyond these research design features, we carried out further checks to assess the robustness of our results. First, we assessed within-panel correlations using Wooldridges's test for serial correlation (the xtserial command in STATA - Drukker (2003)). As the null hypothesis of no serial correlation was rejected, we re-ran all our models using firm-level clustering to obtain consistent estimates and validated that our results were unchanged. Second, we ran diagnostics for multi-collinearity (using the estat vif procedure in STATA after running an OLS regression) and found no significant issues. Third, we tested the sensitivity of our results with an additional period's lag for the predictor and control variables and found similar results. Fourth, we used alternate measures for firm performance, namely Profit margin and Sales - again our results continued to be supported. Fifth, we included additional control variables for the number of analysts covering a firm and the total level of shareholding of mutual funds in a firm, with no substantive changes in the results. Finally, we used an alternate measure of convergence time for Hypothesis 3-instead of using a continuous measure, we split the time period into three equal windows- early, middle and late convergence. Regression results with these alternate indicator variables are shown in Table 6B - hypothesis 3 continues to be strongly supported.

\section{DISCUSSION}

We study the pressures firms face from external stakeholders during a period of industry convergence sparked by a major technological change. Specifically, we assess how securities analysts react to the similar strategies of established firms from different industries responding to convergence between these industries. We explore these dynamics during the period of convergence between the 
wireline telecom and cable industries, as firms from both industries began to offer similar product bundles facilitated by VoIP technology. We find that to the extent a firm's stock is owned by investors with a preference for 'growth' (generally a characteristic of cable firms at the outset of convergence), analysts' reactions are more positive, controlling for financial performance, capabilities, and other industry and firm factors. Conversely, analysts' reactions are more negative to the extent stocks are held by investors with preferences for 'margins.' The analysts covering cable firms' stocks, speaking to investors interested in long-term revenue growth, appear to focus more on the upside revenue potential associated with bundled strategies, despite increased investments. In contrast, the analysts covering the telecom stocks, speaking to investor audiences focused on margins, attend more to the downside of current investments rather than the prospect of market opportunities from the same strategies. This explanation is consistent with prior research that has focused both on the role of analysts as mediators in equity markets (Zuckerman, 1999), and on the idea that analysts rationally focus on different strategies, actions and metrics, depending on beliefs about what firms and markets are attending to (Aghion and Stein, 2008).

We construct a novel aggregate measure of investors' beliefs using the stated investment objectives of mutual funds investing in a firm. The investor profile that we measure reflects differences in the overall composition of investor preferences ('growth' versus 'margins') across firms in our setting thus capturing differences in how investors assess firm value. As indicated by this measure, at the beginning of the convergence period, investors in cable firms' stocks clearly had a greater 'growth' orientation compared to investors in telecom firms. The divergence in reactions and high correlation of these reactions with prior industry, suggests that firms evaluated in the margins category (telecom) preconvergence were disadvantaged compared to firms from the growth category (cable), although both firms follow similar strategies. But we also theorize and find that as convergence unfolds, firms' investor compositions also begin to converge as more growth-oriented investors begin to own shares of telecom firms, and more margin-oriented investors invest in the stocks of cable firms. As the mix of investors holding a firm's shares converges, the analysts' reactions toward similar strategies and strategic investments also converges. The eventual convergence in categories and reactions underscores the 
importance of the pressures earlier in the period. While firms are changing strategies and making investments to adapt to technological and industry change, outdated investor categories continue to shape investor and analyst reactions to firms' strategies for a time. These reactions from analysts are likely to further differentially enable strategies of the growth category firms compared to margin category firms by influencing investor behavior as well as management attention and commitment, thus shaping and reinforcing path-dependent firm heterogeneity in a rapidly changing environment.

It is important to note that we achieve consistent and robust results despite a small dataset that is restricted by our empirical context, thus suggesting a large effect size between the hypothesized variables. We believe the findings and implications of our study are generalizeable more broadly, beyond settings of industry convergence, to understanding important constraints on firms that pursue strategies that are misaligned with the pre-change expectations of important stakeholders. However, studying a setting of industry convergence offers advantages for our analyses in allowing us to control for alternative explanations. We are able to control for analysts' and investors' underlying assessments of the attractiveness of the new product/market domain, since the firms in our study are entering and participating in the same market. In addition, studying industry convergence allows us to control for investors' and analysts' underlying assessment of the wisdom of a bundled strategy, since the firms in our study are offering similar product bundles in the new domain.

Our study design and controls also allow us to address several other alternative explanations. We control for the possibility that differences in analysts' reactions arise from actual differences in firm capabilities or financial performance. We control for these factors in our analysis both with financial and patent control variables, and also with the use of firm fixed effects controls that allows us to control for unobserved heterogeneity. We show that even after controlling for heterogeneity in capabilities and performance, systematic differences in reactions persist and are significantly influenced by a firm's composition of investors and associated expectations about how value is created. This provides stronger evidence that it is specifically the expectations associated with the particular stock category that influences analysts' reactions. 
In addition, beyond our use of quantitative controls, evidence from the texts of the analysts' reports, and separately, texts of earnings conference calls (not shown here) suggest further that neither the cable firms' nor the telecom firms' VoIP-based offerings or bundles were profitable at the outset. Similarly, increased investments were required for both groups of firms to provide the bundled offerings that marked industry convergence. It is apparent in the texts, however, that analysts were focused on growth prospects for cable firms like Comcast, leading them to be enthusiastic about the role of bundled products in spurring additional revenue growth, despite these increased investments and the absence of profits. At the same time, we show in text excerpts that Verizon's analysts were focused mainly on the magnitude of investments and the shorter-term effects on margins. This suggests, supporting the importance of categories in institutional pressures (e.g. Zuckerman \& Rao, 2004; Benner, 2007; Aghion $\&$ Stein, 2008), that it is the focus on different metrics and valuation models associated with different categories that makes the same strategies more legitimate for some firms than others. Beyond our controls for firms' technological capabilities, there is also qualitative evidence in this study that the different reactions do not arise from a belief that one group of firms lack capabilities relative to the other group. For example, analysts are positive about a cable firm's (Charter Communications) future potential in telephony even after noting that at the time it lacked the capabilities or resources to enter the market:

If Charter was not limited by its capital structure, we believe the two biggest areas of upside... would be high speed data and VOIP telephony unit growth (Morgan Stanley, Feb'04)

This suggests that it is membership in the category of 'growth' stocks - a general characteristic of cable firms during this period - that confers legitimacy on Charter's possible activities in VoIP, and not any firm-specific capabilities. Similarly, as we show above, analysts note that Verizon's "capabilities are second to none," but still focus negatively on the challenges (Morgan Stanley, Sept. 2005).

Another alternative explanation is perhaps that analysts are simply anticipating differences in future performance outcomes for firms. As firms "know more than they make," (Brusoni, Principe, \& Pavitt, 2001), analysts may, for example, be using their assessments of firms' broader technological capabilities as an indicator of future success. In addition to including the patent count and citations in our 
regression models, we also analyzed the firm-by-firm patenting pattern and the citations by technological category to ascertain differences in the technological potential of firms. Table 8 shows the number of patents and the number of forward citations for these patents by technological category for both groups of firms. It is apparent from this data that that telecom firms have broader and deeper technological capabilities in electrical, electronic and computer technologies than cable firms. Moreover, from a complementary capabilities standpoint, telecom firms had a larger customer base than cable firms, which should provide them a greater advantage in selling bundled products to existing customers (Teece, 1986). They also possessed distribution channels and brand names that are considered as valuable resources for entering new markets or defending existing ones. Indeed from a capability or complementary asset perspective, one would expect analysts to be more positive to telecom firms' strategies than to cable firms' strategies. Therefore it is not evident why analysts and investors would perceive telecom firms' entry into video services to be a far riskier, less profitable or more technologically challenging undertaking than cable firms' entry into telephone services.

Another question these findings raise is whether the institutional investor behavior we hypothesize about and measure is reflective of broader stock market behavior. In a supplementary analysis, we conducted an event study to estimate abnormal stock market returns to measure aggregate investor reactions to strategy announcements of the two groups of firms during the convergence period. We include events such as announcements of prototypes and commercialization (roll-outs/launches) that are relevant to the firms' convergent strategies (outlined in Tables 1 and 2). We use a standard event study approach as outlined in McWilliams and Siegel (1997) that is based on estimating a market model for each firm-event and then calculating abnormal returns (difference between actual and expected returns) for these events. ${ }^{15}$ We estimate the abnormal returns using EVENTUS ${ }^{16}$ for 17 telecom firm events and 18 cable firm events that were announced during the convergence period. We estimated these returns for each firm-event over four different time periods- 1 day, 2 days, 3 days and 1 week. Table 9

\footnotetext{
${ }^{15}$ See McWilliams and Siegel (1997) for an overview and criticisms of the event study technique. Also see Sood and Tellis (2008) for an event study in the context of technological innovation.

${ }^{16}$ See Arthaud-Day, Certo, and Dalton (2006) for an example of EVENTUS in management research
} 
shows the results of our event study. As the results indicate, investors reacted more positively to announcements of cable firms' offerings than to announcements of similar offerings by telecom firms. The telecom firms experienced (on average) negative abnormal returns while the cable firms experienced positive abnormal returns. The magnitude of the difference between these groups of firms is striking - the telecom firms experienced an average abnormal return of $-2.25 \%$ and the cable firms experienced an average abnormal return of $+2.09 \%$ in the week following the announcement- a difference of $4.34 \%$. Prior studies have generally found abnormal returns in the $0.5 \%$ range (Woolridge and Snow, 1990).

Finally, it also appears that analysts' divergent reactions were not correct assessments of differences in firms' eventual prospects or performance. Texts from analysts' reports included above and our tests for Hypothesis 4 show that despite the negative reactions early on, analysts later begin to see promise in Verizon's and Qwest's bundled strategies. Recent developments also indicate that Verizon has presented a serious threat to Comcast through the ability to offer comparable bundles of services (Fernandez, 2007; Fung, 2007). Verizon and AT\&T's capabilities in fact allow for a 'quadruple play' offering of phone services, Internet, video, and wireless, which has spurred the need for additional responses by cable firms to compete successfully through entry into wireless telephone services (Crockett, 2007).

\section{Contributions}

This study contributes to research at the intersection of strategy, organization theory, and technological change. While prior work in the technological change literature has focused predominantly on the role of firms' internal capabilities in enabling or constraining their efforts to respond to radical technological change, we highlight the role of firms' external constituents, in particular the expectations and preferences of financial analysts and investors, in such contexts. Our consistent and robust finding (despite our small sample) that these inertial expectations and preferences may differentially promote or constrain firms' strategic responses to technological change, underscores the importance of looking beyond firms' capabilities in attempting to understand the heterogeneity in their adaptation efforts. Radical technological change, and in particular industry convergence triggered by a technological change, 
provides a natural experiment that puts firms from different industries in direct competition with each other, thus allowing us to exploit pre-convergence differences in investor and analyst expectations across firms. Thus, we add to the growing stream of research on industry convergence by uncovering the potential for heterogeneity and path-dependence to be reinforced by stock market categories and analysts. In addition, our work contributes to research in organization theory, and specifically to research in institutional change. While evidence on categorical pressures and the penalties associated with deviating from categories has been well documented in institutional theory research, there has been less attention on understanding contexts that allow categorical boundaries to be more fluid and potentially shift (Dacin et al, 2002). Although institutional theorists have suggested that technological shocks may precipitate deinstitutionalization (Greenwood et al, 2002), research has yet to explore the mechanisms by which this happens. Our study provides insights into change in the categories in which firms are embedded and the resulting changes in the pressures firms face. Recent research that is more specific to the topic of firms' responses to technological change has suggested that institutional forces might affect different organizations differently. For instance, Sine, Haveman and Tolbert (2005) suggest there are differential institutional implications for firms that invest in new technologies versus existing technologies, while Khessina and Carroll (2008) show that de novo firms might be forced to conform more to institutional expectations than de alio firms. In contrast, our work addresses the systematic divergence in pressures from institutions for de alio firms from different industries that are following similar product-market strategies using the same technology. Our work also contributes to management practice. Managers' challenges in responding to new opportunities in technologically convergent settings may extend beyond the already considerable challenge of overcoming inertia and developing new capabilities. These challenges may be exacerbated by the negative reactions of analysts and financial markets to the strategic changes and investments required to enter these markets, as well as by the simultaneous positive reactions that reward and legitimate the entry of competitors. Our findings further underscore the potential for managers to proactively shift the composition and associated expectations of stakeholders to allow for the strategic changes required to adapt to major environmental changes. 


\section{Future Research}

This work also suggests fruitful avenues for future research. As our study is aimed at understanding analysts' reactions as an indicator of perceptions of legitimacy as firms pursue strategies to respond to a new technology, we do not explore how these reactions influenced firms' subsequent strategies. Prior research has shown that financial market and analyst reactions influence firms' strategies and actions (Rao \& Sivakumar, 1999; Zuckerman, 2000; Bushee, 1998; Benner and Ranganathan, forthcoming), suggesting that these findings have further implications for differences in the strategies firms undertake. Another topic for future research is to gain a better understanding of whether and to what extent analysts' reactions result from biases and the nature of these biases. Research in accounting and finance for example, has found that analysts display an optimistic bias toward the firms they cover (Francis \& Philbrick, 1993; Michaely \& Womack, 1999), because they are dependent on information from managers, or because their employers hold shares of the firms' stocks. More generally, research has shown that analysts are influenced by career concerns that cause biased forecasts or herding, i.e. ignoring their own private information and following the consensus even if the consensus is wrong (e.g. Hong \& Kubik, 2003; Hong, Kubik, and Solomon, 2000). Finally, although we document shifts in categories arising from investors updating their portfolios and the associated shifts in analysts' reactions, we do not discuss firm-level characteristics that may accelerate or slow down these shifts. For instance, influential managers may act as entrepreneurial agents to catalyze the shifts in institutional categories or may use their influence to maintain current categorical expectations to their advantage (Zuckerman and Rao, 2004). Other firms may undertake impression management (Westphal and Graebner, 2010) and favor rendering activities to improve analyst ratings (Westphal and Clement, 2008) or placate investors (Westphal and Bednar, 2008). Future research that undertakes an in-depth analysis of the process of change will be able to provide richer insights on these possibilities. 


\section{REFERENCES}

Abernathy, W J., J. Utterback. 1978. Patterns of industrial innovation. Technology Review, 80(7):40-47

Agarwal, R., C. E. Helfat. 2009. Strategic renewal of organizations. Organization Science. 20(2) 281-293.

Aghion, P. \& Stein, J. 2008. Growth vs. margins: Destabilizing consequences of giving the stock market what it wants. The Journal of Finance, 63:1025.

Ahuja, G., Katila, R., 2001. Technological acquisition and the innovative performance of acquiring firms: a longitudinal study. Strategic Management Journal. 22, 197-220.

Amihud, Y. \& Lev, B. 1981. Risk reduction as a managerial motive for conglomerate mergers. Bell Journal of Economics, 12: 605-617.

Arthaud-Day, M., Certo, S. T., Dalton, C. M., \& Dalton, D. R. 2006. A changing of the guard: Executive and director turnover following corporate financial restatements. Academy of Management Journal, 49.

Baik, B., D.B. Farber., and K. Petroni. 2009. Analysts' incentives and street earnings. Journal of Accounting Research, 47 (1): 45-69.

Barber, B. R. Lehavy, M. McNichols, and B. Trueman, 2001. Can investors profit from the prophets? Security analyst recommendations and stock returns. Journal of Finance, 56: 531-564.

Barniv, R., Hope, O., Myring, M., Thomas, W. 2009. Do analysts practice what they preach and should investors listen? Effects of recent regulations. The Accounting Review 84, 1015 -1040.

Benner, M.J. 2007. The incumbent discount: Stock market categories and response to radical technological change. Academy of Management Review.

Benner, M. J. 2010. Securities Analysts and Incumbent Response to Radical Technological Change: Evidence from Digital Photography and Internet Telephony. Organization Science, 21(1): 42-62

Benner, M.J. and Ranganathan, R. 2011. Offsetting illegitimacy? How pressures from securities analysts influence incumbents in the face of new technologies. Academy of Management Journal, Forthcoming.

Benner, M.J. and Tushman, M. 2002. Process management and technological innovation: A longitudinal study of the photography and paint industries. Administrative Science Quarterly, 47, 676-706.

Berger, Philip G., and Eli Ofek, 1995, Diversification's effect on firm value, Journal of Financial Economics 37, 39-65.

Beunza, D., R. Garud. 2007. Calculators, lemmings or frame-makers? The intermediary role of securities analysts. M. Callon, Y. Millo, F. Muniesa, eds. Market Devices. Blackwell, London.

Bjerring, J. H., J. Lakonishok, and T. Vermaelen, 1983, Stock prices and financial analysts' recommendations, Journal of Finance, 38:187-204.

Boni, L., Womack, K. 2002. Wall Street's credibility problem: Misaligned incentives and dubious fixes? Brookings-Wharton Papers on Financial Services, 93-128.

Bradshaw, M. 2004. How do analysts use their earnings forecasts in generating stock recommendations? The Accounting Review, 79: 25-50.

Brusoni, S., Prencipe, A. \& Pavitt, K. 2001. Knowledge specialization, organizational coupling, and the boundaries of the firm: Why do firms know more than they make? Administrative Science Quarterly, 46: 597-621.

Bushee, B.J. 1998. The influence of institutional investors on myopic R\&D investment behavior. The Accounting Review, 73, 305-333. 
Collis, D.J., Bane, P.W. and Bradley, S.P. 1997. Winner and losers - industry structure in the converging world of telecommunications, computing and entertainment. In Competing in the Age of Digital Convergence, ed. D.B. Yoffie. Harvard Business School Press, Boston.

Crockett, R.O. 2007. A cable company people don't hate; How Cox is keeping customers happy and stealing business from the phone giants. Business Week, May 28, pg. 73.

Dacin, T., Goldstein, J., \& Scott, W. R. 2002. Institutional theory and institutional change: Introduction to the special research forum. Academy of Management Journal, 45(1): 45-56.

Das, S., Levine, C., Sivaramakrishnan, K. 1998. Earnings predictability and bias in analysts' earnings forecasts. The Accounting Review 73, 277-294.

Davis, G. F. 2005. New directions in corporate governance. Annual Review of Sociology. 31(1) 143-162.

De Franco, G., H. Lu, and F.P. Vasvari. 2007. Wealth transfer effects of analysts' misleading behavior. Journal of Accounting Research 45, 71-110.

Deutsche Bank investment reports on Verizon, BellSouth, AT\&T, SBC, Qwest, Comcast, Cablevision, Charter Communications, and Time Warner, 2002-2008. Thomson Reuters.

Drukker, D. 2003. Testing for serial correlation in linear panel-data models. Stata Journal, 3(2): 168-177.

Dutton, J.E. and S.E. Jackson. 1987. Categorizing strategic issues: Links to organizational action. Academy of Management Review, 12: 76-90.

Ertimur, Yonca, Volkan Muslu, and Frank Zhang, 2010, Why are Recommendations Optimistic? Evidence from Analysts' Coverage Initiations, Review of Accounting Studies, Forthcoming.

Fernandez, B. 2007. Comcast shares slide 11 pct. The Philadelphia Inquirer, October 26, CITY-D-01.

Francis, J. and D. Philbrick, 1993. Analysts' decisions as products of multi-task environment. Journal of Accounting Research, 31: 216-230.

Fung, A. 2007. Verizon's big bet on fiber finally yields dividends. Crain's New York Business, October 8.

Goldfarb, B., D. A. Kirsch, and D. Miller. 2007. Was there too little entry during the dot com era. Journal of Financial Economics, 86:100-144.

Greenstein, S. and T. Khanna. 1997. What does industry convergence mean? D. Yoffie, ed. Competing in the Age of Digital Convergence. Harvard Business School Press, Boston, MA.

Greenwood, R., R. Suddaby, and C.R. Hinings. 2002. Theorizing change: The role of professional associations in the transformation of institutional fields. Academy of Management Journal, 45(1):58-80

Hall, B., Jaffe, A. and M.Trajtenberg. 2001. Market Value and Patent Citations: A First Look. Rand Journal of Economics, 36 (2005):16-38

Helfat, C. and M. Lieberman., 2002. The birth of capabilities: Market entry and the importance of prehistory. Industrial and Corporate Change, 11(4): 725-760.

Henderson, R.M. and Clark, K. B. 1990. Architectural Innovation: The reconfiguration of existing product technologies and the failure of established firms. Administrative Science Quarterly, 35, 9-30.

Henderson, R. 1993. Underinvestment and incompetence as responses to radical innovation: Evidence from the photolithographic equipment industry. Rand Journal of Economics, 24: 248-270.

Hong, H. and J. Kubik, 2003. Analyzing the analysts: Career concerns and biased forecasts. Journal of Finance, 58: 313-351.

Hong, H., J. D. Kubik, and A. Solomon, 2000. Security analysts career concerns and herding of earnings forecasts. RAND Journal of Economics, 31, 121-144

Institutional Investor Magazine, 2011. The 2010 All-America Research Team. 
Jegadeesh, N., Kim, J., Krische, S., Lee, C., 2004. Analyzing the analysts: When do recommendations add value? Journal of Finance 59, 1083-1124.

Kahn, C. and A. Winton, 1998. Ownership structure, speculation, and shareholder intervention. The Journal of Finance 53: 99-129.

Khessina OM, Carroll GR. 2008. Product demography of de novo and de alio firms in the optical disk drive industry, 1983-1999. Organization Science, 19(1): 25-38.

Klepper, S. \& K. Simons. 2000. Dominance by birthright: Entry of prior radio producers and competitive ramifications in the U.S. television receiver industry. Strategic Management Journal, 21: 997-1016.

Kotha, S. and A. Nair, 1995. Strategy and environment as determinants of performance: Evidence from the Japanese machine tool industry. Strategic Management Journal, 16: 497-518.

Lavie, D. 2006. Capability reconfiguration: An analysis of incumbent responses to technological change. Academy of Management Review, 31: 153-174.

Leonard-Barton, D. 1992. Core capabilities and core rigidities: A paradox in managing new product development. Strategic Management Journal, 13, 111-125.

Levinthal, D. and March, J.G., 1993. The myopia of learning. Strategic Management Journal, 14: 95-112. Lipper. 2008. Worldwide Holdings-Based Fund Classification Methodology. Thomson-Reuters.

Litov, L., P. Moreton, and T. Zenger, 2009. Corporate strategy, analyst coverage, and the uniqueness paradox. Working paper.

March, 1991. Exploration and exploitation in organizational learning. Organization Science, 2: 71-87.

Maritan, C. A. 2001. Capital investment as investing in organization capabilities: An empirically grounded process model. Academy of Management Journal, 44: 513-531.

McWilliams, A., and D. Siegel. 1997. Event studies in management research: Theoretical and empirical issues. Academy of Management Journal, 40: 626-657.

Michaely, R. and K. Womack, 1999. Conflict of interest and the credibility of underwriter analyst recommendations. Review of Financial Studies, 12: 573-608.

Miller, K. and P. Bromiley, 1990. Strategic risk and corporate performance: An analysis of alternative risk measures. Academy of Management Journal, 33: 756-779.

Mitchell, W. 1991. Dual clocks: Entry order influences on incumbent and newcomer market share and survival when specialized assets retain their value. Strategic Management Journal, 12:85-100.

Mohammed, A. 2006. Verizon lays it on the line; CEO sticks by costly rollout of fiber-optic network. The Washington Post, Financial section; D01.

Mola, S., \& Guidolin, M. 2009. Affiliated mutual funds and analyst optimism. Journal of Financial Economics, 93, 108-137.

Morgan Stanley reports on Verizon, BellSouth, SBC, AT\&T, Qwest, Comcast, Cablevision, Charter Communications, and Time Warner, 2002-2008. Thomson Reuters.

Ocasio W. 1997. Towards an attention-based view of the firm. Strategic Management Journal, Summer Special Issue 18: 187-206.

Qian, H. 2009. Time Variation in Analyst Optimism: An Investor Sentiment Explanation. Journal of Behavioral Finance, 10: 182-193.

Rao, H. and Sivakumar, K. 1999. Institutional sources of boundary-spanning structures: The establishment of investor relations departments in the Fortune 500 industrials. Organization Science, $10(1), 27-42$. 
Reinganum, J. 1983. Uncertain innovation and the persistence of monopoly. The American Economic Review, 73, 741-748.

Schipper, K. 1991. Analysts’ forecasts. Accounting Horizons, 5, 105-121.

Schumpeter, J. 1942. Capitalism, Socialism, and Democracy. Harper: New York.

Shleifer, A. 2001. Inefficient markets: An introduction to behavioral finance. Oxford University Press

Sine, W., H. Haveman, and P. Tolbert. 2005. "Risky Business; Entrepreneurship in the New Independent Power Sector.” Administrative Science Quarterly 50:200-32.

Sood, Ashish and Gerard J. Tellis. 2008. Do innovations really payoff? Total stock market returns to innovation. Marketing Science, 28 (3), 442-456.

Srinivasan, R., Haunschild, P., \& Grewal, R. 2007. Vicarious learning in new product introductions in the early years of a converging market. Management Science, 53(1): 16-28.

Stuart, T.E., J.M. Podolny. 1996. Local search and the evolution of technological capabilities. Strategic Management Journal, 17:21-38.

Sull, D., Tedlow, R., and Rosenbloom, R. 1997. Managerial commitments and technology change in the U.S. tire industry. Industrial and Corporate Change, 6, 461-500.

Teece, D. 1986. Profiting from technological innovation: Implications for integration, collaboration, licensing and public policy." Research Policy, 15: 285-305.

Tripsas, M. 2009. Technology, identity and inertia through the lens of "The Digital Photography Company." Organization Science, 20: 440-461.

Tripsas, M. and Gavetti, G. 2000. Capabilities, cognition, and inertia: Evidence from digital imaging. Strategic Management Journal, 21, 1147-1161.

Tushman, M.L. and Anderson, P. 1986. Technological discontinuities and organizational environments. Administrative Science Quarterly, 31, 439-465.

Useem, M. 1996. Investor Capitalism. New York: Basic Books

Westphal, J. D., \& Bednar, M. 2008. The pacification of institutional investors. Administrative Science Quarterly, 53: 29-72.

Westphal, J. D. \& Clement, M.B. 2008. Sociopolitical dynamics in relations between top managers and security analysts: Favor rendering, reciprocity, and analyst stock recommendations. Academy of Management Journal, 51: 873-897.

Westphal, J.D. \& Graebner, M.E. 2010. A matter of appearances: How corporate leaders manage the impressions of financial analysts about the conduct of their boards. Academy of Management Journal, 53: $15-44$

Womack, K. 1996. Do brokerage analysts' recommendations have investment value? Journal of Finance, 47: 137-167.

Woolridge, J.R. and Snow, C. 1990. Stock market reaction to strategic investment decisions. Strategic Management Journal, 11, 5, September: 353-363.

Yoffie, D. B. 1997. Competing in the age of digital convergence. Harvard Business School Press.

Zuckerman, E. 1999. The categorical imperative: Securities analysts and the illegitimacy discount. American Journal of Sociology, 104(5), 1398-1438.

Zuckerman, E. 2000. Focusing the corporate product: Securities analysts and de-diversification. Administrative Science Quarterly, 45(3), 591-619.

Zuckerman, E. and H. Rao, 2004. Shrewd, crude or simply deluded? Comovement and the Internet stock phenomenon. Industrial and Corporate Change, 13: 171-21. 
TABLE 1 -Timeline of Telecom firms' new products/services during the period of convergence

\begin{tabular}{|l|l|l|}
\hline Date & Firm & Event Description \\
\hline May 2003 & Bellsouth, SBC, VZ & Announce common technical requirements for Fiber initiatives \\
\hline Dec 2003 & SBC & Announces alliance with Alcatel for Fiber initiative \\
\hline Apr 2004 & AT\&T & Launches CallVantage VoIP offering \\
\hline May 2004 & Bellsouth & Rolls out IP Centrex VoIP service to business customers \\
\hline Jun 2004 & Bellsouth & Rolls out residential VoIP in Columbia, SC, FL \\
\hline Jun 2004 & Qwest & Launches OneFlex VoIP product business and consumer markets \\
\hline Jul 2004 & AT\&T & CallVantage launch complete - expanded to more than 100 US markets \\
\hline Jul 2004 & Verizon & Launches Voicewing VoIP services to residential customers \\
\hline Oct 2004 & Verizon & Announces rollout plans for FiOS in northeastern US \\
\hline Nov 2004 & SBC & Announces launch of residential VoIP service for its DSL customers \\
\hline Apr 2005 & Verizon & Introduces FiOS broadband in trial markets \\
\hline Sep 2005 & Verizon & Rolls out Fiber Optic TV service as part of FiOS triple-play \\
\hline Dec 2005 & Bellsouth & Announces launch of consumer VoIP service in partnership with 8x8 \\
\hline Feb 2006 & Qwest & Announces plans to bundle video with phone and internet products \\
\hline Feb 2006 & AT\&T & Trials U-verse (Fiber based bundle) in Nevada \\
\hline
\end{tabular}

TABLE 2 - Timeline of Cable firms' new products/services during the period of convergence

\begin{tabular}{|l|l|l|}
\hline Date & Firm & Event Description \\
\hline Early 2002 & Time Warner & Announces Cable VoIP plans in conjunction with partners \\
\hline May 2003 & Cablevision & Trials residential VoIP product \\
\hline Aug 2003 & Time Warner & Tests 'Digital Phone' VoIP service \\
\hline Nov 2003 & Cablevision & Launches 'Optimum Voice' -residential VoIP product \\
\hline May 2004 & Comcast & Announces 'Digital Voice' residential VoIP product rollout for 2005/06 \\
\hline Jun 2004 & Cablevision & Announces bundling of Internet and phone product \\
\hline Aug 2004 & Charter & Announces VoIP plans in conjunction with partners \\
\hline Dec 2004 & Cablevision & Announces expansion of VoIP service \\
\hline Jan 2005 & Comcast & First rollouts of Digital Voice \\
\hline Feb 2005 & Time Warner & Launches 'TW Telecom One Solution' VoIP service for businesses \\
\hline Nov 2005 & Charter & Announces cable web telephone \\
\hline Apr 2006 & Charter & Introduces VoIP service \\
\hline Apr 2008 & Time Warner & Expands video and phone bundle into California \\
\hline
\end{tabular}




\section{TABLE 3: Correlation matrix}

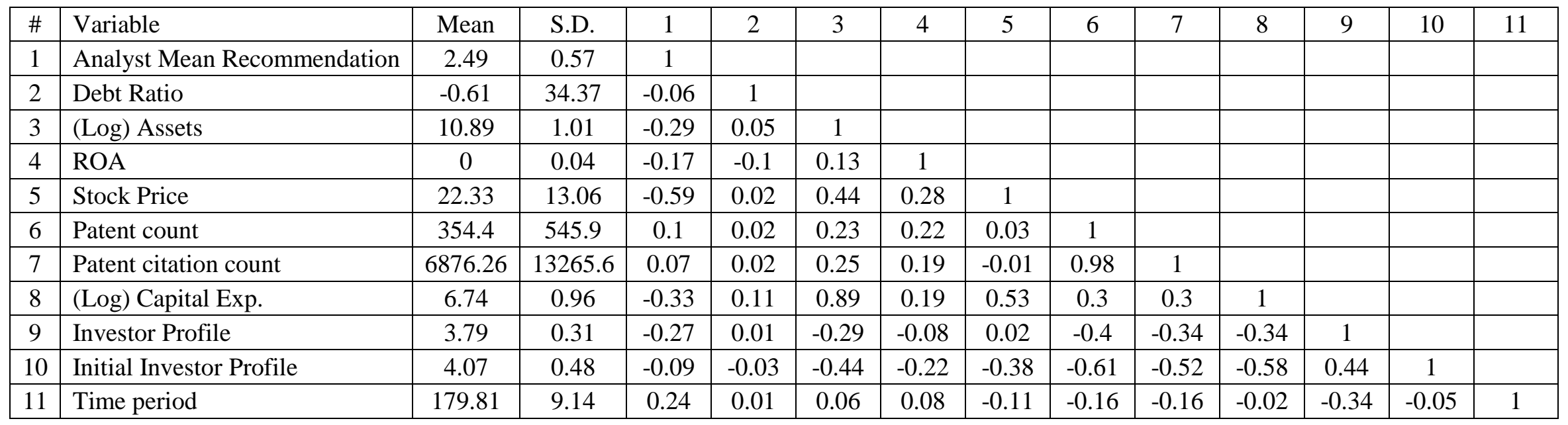

TABLE 4: Difference of Means t-test between Telecom and cable firms for Mean analyst recommendation and Investor profile

\begin{tabular}{|l|c|c|c|c|c|c|}
\hline \multicolumn{1}{|c|}{ Variable } & $\underline{\text { Telecom firms }}$ & $\underline{\text { Cable firms }}$ & $\underline{\text { Difference }}$ & $\underline{\text { Std Err }}$ & $\underline{\text { T-Test 't' }}$ & p-value \\
\hline $\begin{array}{l}\text { Dependent Variable: } \\
\text { Mean analyst recommendation }\end{array}$ & 2.65 & 2.31 & 0.34 & 0.074 & 4.45 & $<.0001$ \\
\hline $\begin{array}{l}\text { Independent Variable: } \\
\text { Investor profile }\end{array}$ & 3.68 & 4.45 & -0.77 & 0.062 & -12.2 & $<.00001$ \\
\hline
\end{tabular}

Note:

(1) Lower values of Mean Analyst Recommendation indicate more positive analyst recommendations

(2) Lower values for Investor Profile indicates a greater investor focus on margins vs. growth 
TABLE 5: Divergence of analyst reactions. Panel data models (GLS) with random or fixed effects. Dependent variable is Mean Analyst Recommendation for firm ' $i$ ' in period ' $t$ '. (Note: Lower (higher) values of the dependent variable indicate more positive (negative) reactions)

\begin{tabular}{|c|c|c|c|c|c|c|c|c|}
\hline \multirow[b]{2}{*}{ VARIABLES } & \multicolumn{4}{|c|}{ Random effects models } & \multicolumn{4}{|c|}{ Firm fixed effects models } \\
\hline & $\begin{array}{c}(1) \\
\text { Ctrls only }\end{array}$ & $\begin{array}{l}(2) \\
\mathrm{H} 1 \\
\end{array}$ & $\begin{array}{l}(3) \\
\mathrm{H} 2 \\
\end{array}$ & $\begin{array}{c}(4) \\
\text { w/o patents } \\
\end{array}$ & $\begin{array}{c}(5) \\
\text { Ctrls only }\end{array}$ & $\begin{array}{l}(6) \\
\mathrm{H} 1 \\
\end{array}$ & $\begin{array}{l}(7) \\
\mathrm{H} 2 \\
\end{array}$ & $\begin{array}{c}(8) \\
\text { w/o patents }\end{array}$ \\
\hline Predictors & & & & & & & & \\
\hline Investor Profile (t-1) & & $\begin{array}{c}-0.2730 * * \\
(0.1381)\end{array}$ & $\begin{array}{c}-0.4806 * * * \\
(0.1303)\end{array}$ & $\begin{array}{c}-0.2927 * * * \\
(0.1013)\end{array}$ & & $\begin{array}{c}-0.3626 * * \\
(0.1458)\end{array}$ & $\begin{array}{c}-0.6235 * * * \\
(0.1519)\end{array}$ & $\begin{array}{c}-0.3066 * * * \\
(0.1103)\end{array}$ \\
\hline Investor Profile X (Log) Capital Exp.(t-1) & & & $\begin{array}{c}-0.6361 * * * \\
(0.1204)\end{array}$ & $\begin{array}{c}-0.4239 * * * \\
(0.1014)\end{array}$ & & & $\begin{array}{c}-0.6409 * * * \\
(0.1616)\end{array}$ & $\begin{array}{c}-0.4332 * * * \\
(0.1145)\end{array}$ \\
\hline Controls & & & & & & & & \\
\hline 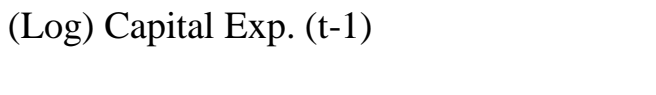 & $\begin{array}{l}-0.0833 \\
(0.0883)\end{array}$ & $\begin{array}{c}-0.0816 \\
(0.0872)\end{array}$ & $\begin{array}{l}-0.1246 \\
(0.0788)\end{array}$ & $\begin{array}{c}-0.1500 * * \\
(0.0727)\end{array}$ & $\begin{array}{c}-0.2456 * * \\
(0.0954)\end{array}$ & $\begin{array}{c}-0.2454 * * * \\
(0.0932)\end{array}$ & $\begin{array}{l}-0.1761 * \\
(0.0892)\end{array}$ & $\begin{array}{c}-0.2297 * * * \\
(0.0828)\end{array}$ \\
\hline Industry control $(1=$ cable, $0=$ telco $)$ & $\begin{array}{c}-0.6790 * * * \\
(0.0824)\end{array}$ & $\begin{array}{c}-0.5827 * * * \\
(0.0949)\end{array}$ & $\begin{array}{c}-0.5271 * * * \\
(0.0860)\end{array}$ & $\begin{array}{c}-0.6610 * * * \\
(0.0628)\end{array}$ & Drops out & Drops out & Drops out & Drops out \\
\hline Debt Ratio (t-1) & $\begin{array}{l}-0.0004 \\
(0.0006)\end{array}$ & $\begin{array}{c}-0.0004 \\
(0.0006)\end{array}$ & $\begin{array}{c}0.0005 \\
(0.0006)\end{array}$ & $\begin{array}{c}0.0001 \\
(0.0006)\end{array}$ & $\begin{array}{l}-0.0000 \\
(0.0006)\end{array}$ & $\begin{array}{c}0.0001 \\
(0.0006)\end{array}$ & $\begin{array}{c}0.0009 \\
(0.0006)\end{array}$ & $\begin{array}{c}0.0004 \\
(0.0005)\end{array}$ \\
\hline$(\log )$ Assets $(\mathrm{t}-1)$ & $\begin{array}{c}-0.3676 * * * \\
(0.0811)\end{array}$ & $\begin{array}{c}-0.3727 * * * \\
(0.0802)\end{array}$ & $\begin{array}{c}-0.3394 * * * \\
(0.0724)\end{array}$ & $\begin{array}{l}-0.0922 \\
(0.0562)\end{array}$ & $\begin{array}{l}-0.1236 \\
(0.1452)\end{array}$ & $\begin{array}{l}-0.0595 \\
(0.1442)\end{array}$ & $\begin{array}{c}-0.1804 \\
(0.1388)\end{array}$ & $\begin{array}{l}-0.1591 \\
(0.1169)\end{array}$ \\
\hline $\mathrm{ROA}(\mathrm{t}-1)$ & $\begin{array}{l}-2.6513 \\
(1.6440)\end{array}$ & $\begin{array}{l}-2.8423 * \\
(1.6264)\end{array}$ & $\begin{array}{l}-1.1417 \\
(1.4978)\end{array}$ & $\begin{array}{l}-1.2999 \\
(1.1111)\end{array}$ & $\begin{array}{l}-0.5107 \\
(1.6592)\end{array}$ & $\begin{array}{l}-0.2798 \\
(1.6241)\end{array}$ & $\begin{array}{c}0.6382 \\
(1.5418)\end{array}$ & $\begin{array}{c}0.0833 \\
(1.1367)\end{array}$ \\
\hline Stock Price $(\mathrm{t}-1)$ & $\begin{array}{l}-0.0048 \\
(0.0043)\end{array}$ & $\begin{array}{l}-0.0050 \\
(0.0043)\end{array}$ & $\begin{array}{c}-0.0087 * * \\
(0.0039)\end{array}$ & $\begin{array}{c}-0.0174 * * * \\
(0.0020)\end{array}$ & $\begin{array}{c}-0.0215 * * * \\
(0.0080)\end{array}$ & $\begin{array}{l}-0.0153 * \\
(0.0082)\end{array}$ & $\begin{array}{l}-0.0082 \\
(0.0079)\end{array}$ & $\begin{array}{l}-0.0073^{*} \\
(0.0041)\end{array}$ \\
\hline Patent count $(\mathrm{t}-1)$ & $\begin{array}{l}-0.0005 \\
(0.0003)\end{array}$ & $\begin{array}{l}-0.0005 \\
(0.0003)\end{array}$ & $\begin{array}{l}-0.0003 \\
(0.0003)\end{array}$ & & $\begin{array}{l}-0.0010 \\
(0.0012)\end{array}$ & $\begin{array}{l}-0.0010 \\
(0.0011)\end{array}$ & $\begin{array}{c}0.0005 \\
(0.0011)\end{array}$ & \\
\hline Patent citation count $(\mathrm{t}-1)$ & $\begin{array}{c}0.0000 * * \\
(0.0000)\end{array}$ & $\begin{array}{c}0.0000 * * \\
(0.0000)\end{array}$ & $\begin{array}{c}0.0000 \\
(0.0000)\end{array}$ & & $\begin{array}{c}0.0000 \\
(0.0000)\end{array}$ & $\begin{array}{c}0.0000 \\
(0.0000)\end{array}$ & $\begin{array}{l}-0.0000 \\
(0.0000)\end{array}$ & \\
\hline Constant & $\begin{array}{c}7.6892 * * * \\
(0.7169)\end{array}$ & $\begin{array}{c}8.7455 * * * \\
(0.8870)\end{array}$ & $\begin{array}{c}9.4155 * * * \\
(0.8077)\end{array}$ & $\begin{array}{c}6.2739 * * * \\
(0.4768)\end{array}$ & $\begin{array}{c}6.2631 * * * \\
(1.3727)\end{array}$ & $\begin{array}{c}6.7913 * * * \\
(1.3582)\end{array}$ & $\begin{array}{c}8.2973 * * * \\
(1.3300)\end{array}$ & $\begin{array}{c}7.0896 * * * \\
(1.0098)\end{array}$ \\
\hline Period effects? & Yes & Yes & Yes & Yes & Yes & Yes & Yes & Yes \\
\hline Observations & 147 & 147 & 147 & 203 & 147 & 147 & 147 & 203 \\
\hline R-Square & 0.850 & 0.855 & 0.884 & 0.820 & 0.802 & 0.813 & 0.837 & 0.768 \\
\hline Chi-square (re) or F-Statistic (fe) & 653.7 & 674.2 & 861.4 & 760.9 & 14.90 & 15.29 & 17.31 & 15.61 \\
\hline
\end{tabular}

Standard errors in parentheses, *** $\mathrm{p}<0.01, * * \mathrm{p}<0.05, * \mathrm{p}<0.1$ 
TABLE 6A: Convergence of investor profiles. Panel data models (GLS) with random or fixed effects. Dependent variable is Investor Profile for firm ' $i$ ' in period ' $t$ '. (Note: Higher (lower) values of the dependent variable indicate more growth (margin) oriented investors)



Standard errors in parentheses $* * * \mathrm{p}<0.01, * * \mathrm{p}<0.05, * \mathrm{p}<0.1$ 
TABLE 6B: Convergence of investor profiles with alternate measures of convergence time

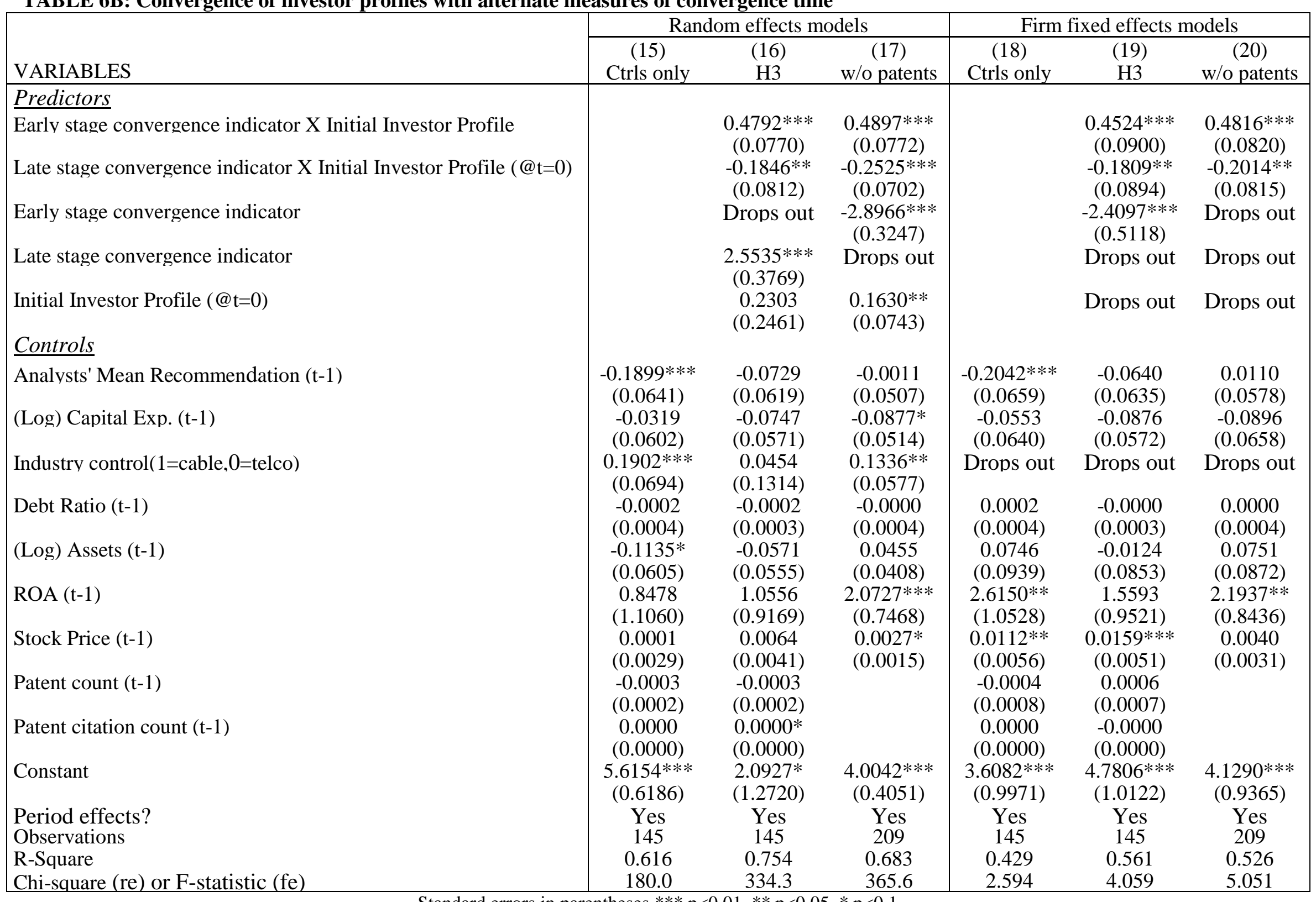
Standard errors in parentheses $* * * \mathrm{p}<0.01, * * \mathrm{p}<0.05,{ }^{*} \mathrm{p}<0.1$

$$
--39--
$$


TABLE 7: Analyst reactions during initial and later stages of convergence. Panel data models (GLS) with random or fixed effects. Dependent variable is Mean Analyst Recommendation for firm ' $i$ ' in period ' $t$ ' (Higher values on the DV indicate more negative reactions)

\begin{tabular}{|c|c|c|c|c|c|c|}
\hline VARIABLES & \multicolumn{3}{|c|}{ Random effects models } & \multicolumn{3}{|c|}{ Firm fixed effects models } \\
\hline Predictors & & & & & & \\
\hline Time period X Initial Investor Profile ( @ $\mathrm{t}=0$ ) & & $\begin{array}{c}0.0231 * * \\
(0.0111)\end{array}$ & $\begin{array}{l}0.0134 * \\
(0.0074)\end{array}$ & & $\begin{array}{c}0.0555^{* * *} * \\
(0.0124)\end{array}$ & $\begin{array}{c}0.0257 * * * \\
(0.0087)\end{array}$ \\
\hline Time period & & $\begin{array}{c}-0.0644 \\
(0.0443)\end{array}$ & $\begin{array}{l}-0.0328 \\
(0.0296)\end{array}$ & & $\begin{array}{c}-0.1916 * * * \\
(0.0494)\end{array}$ & $\begin{array}{c}-0.0710 * * \\
(0.0336)\end{array}$ \\
\hline Initial Investor Profile (@t=0) & & $\begin{array}{c}-5.2555^{* *} \\
(2.1817)\end{array}$ & $\begin{array}{c}-2.6231^{*} \\
(1.3970)\end{array}$ & & Drops out & Drops out \\
\hline Investor Profile X (Log) Capital Exp.(t-1) & $\begin{array}{c}-0.6361 * * * \\
(0.1204)\end{array}$ & $\begin{array}{c}-0.4205 * * * \\
(0.1445)\end{array}$ & $\begin{array}{c}-0.3928 * * * \\
(0.1016)\end{array}$ & $\begin{array}{c}-0.6409 * * * \\
(0.1616)\end{array}$ & $\begin{array}{c}-0.6044 * * * \\
(0.1492)\end{array}$ & $\begin{array}{c}-0.4761 * * * \\
(0.1127)\end{array}$ \\
\hline Investor Profile (t-1) & $\begin{array}{c}-0.4806^{* * * *} \\
(0.1303)\end{array}$ & $\begin{array}{l}-0.1321 \\
(0.1869)\end{array}$ & $\begin{array}{l}-0.1023 \\
(0.1340)\end{array}$ & $\begin{array}{c}-0.6235^{* * * *} \\
(0.1519)\end{array}$ & $\begin{array}{l}-0.1176 \\
(0.1799)\end{array}$ & $\begin{array}{l}-0.1242 \\
(0.1240)\end{array}$ \\
\hline (Log) Capital Exp. (t-1) & $\begin{array}{l}-0.1246 \\
(0.0788)\end{array}$ & $\begin{array}{c}-0.1921 * * \\
(0.0853)\end{array}$ & $\begin{array}{c}-0.1379^{*} \\
(0.0730)\end{array}$ & $\begin{array}{l}-0.1761^{*} \\
(0.0892)\end{array}$ & $\begin{array}{l}-0.1134 \\
(0.0834)\end{array}$ & $\begin{array}{c}-0.1765^{* * *} \\
(0.0828)\end{array}$ \\
\hline Industry control $(1=$ cable, $0=$ telco $)$ & $\begin{array}{c}-0.5271 * * * \\
(0.0860)\end{array}$ & $\begin{array}{l}-0.0024 \\
(0.2337)\end{array}$ & $\begin{array}{c}-0.5622 * * * \\
(0.0780)\end{array}$ & Drops out & Drops out & Drops out \\
\hline ROA (t-1) & $\begin{array}{l}-1.1417 \\
(1.4978)\end{array}$ & $\begin{array}{c}-0.4768 \\
(1.4821)\end{array}$ & $\begin{array}{l}-1.3041 \\
(1.1019)\end{array}$ & $\begin{array}{c}0.6382 \\
(1.5418)\end{array}$ & $\begin{array}{l}1.9061 \\
(1.4496)\end{array}$ & $\begin{array}{c}0.5839 \\
(1.1227)\end{array}$ \\
\hline Stock Price $(\mathrm{t}-1)$ & $\begin{array}{c}-0.0087 * * \\
(0.0039)\end{array}$ & $\begin{array}{c}-0.0227 * * * \\
(0.0064)\end{array}$ & $\begin{array}{c}-0.0185^{* * * *} \\
(0.0021)\end{array}$ & $\begin{array}{c}-0.0082 \\
(0.0079)\end{array}$ & $\begin{array}{c}-0.0167 * * \\
(0.0076)\end{array}$ & $\begin{array}{l}-0.0038 \\
(0.0042)\end{array}$ \\
\hline Patent count (t-1) & $\begin{array}{l}-0.0003 \\
(0.0003)\end{array}$ & $\begin{array}{c}-0.0005^{*} \\
(0.0003)\end{array}$ & & $\begin{array}{c}0.0005 \\
(0.0011)\end{array}$ & $\begin{array}{l}-0.0006 \\
(0.0011)\end{array}$ & \\
\hline Patent citation count $(\mathrm{t}-1)$ & $\begin{array}{c}0.0000 \\
(0.0000)\end{array}$ & $\begin{array}{c}0.0000 \\
(0.0000)\end{array}$ & & $\begin{array}{l}-0.0000 \\
(0.0000)\end{array}$ & $\begin{array}{c}0.0000 \\
(0.0000)\end{array}$ & \\
\hline Constant & $\begin{array}{c}9.4155^{* * *} * \\
(0.8077)\end{array}$ & $\begin{array}{c}22.9708 * * * \\
(8.0932)\end{array}$ & $\begin{array}{c}12.2232 * * \\
(5.3422)\end{array}$ & $\begin{array}{c}8.2973 * * * \\
(1.3300)\end{array}$ & $\begin{array}{l}-1.0880 \\
(2.1183)\end{array}$ & $\begin{array}{c}-0.8017 \\
(1.5493)\end{array}$ \\
\hline Period effects? & Yes & Yes & Yes & Yes & Yes & Yes \\
\hline Observations & 147 & 147 & 203 & 147 & 147 & 203 \\
\hline
\end{tabular}


TABLE 8: Citation flows to patents and patent counts by firm/technological category (Patent counts in parentheses)

\begin{tabular}{|c|c|c|c|c|c|c|c|c|c|c|c|c|c|}
\hline & \multicolumn{5}{|c|}{ Computers and Communications (Tech. Category Code $=2$ ) } & \multicolumn{8}{|c|}{ Electrical and Electronic (Tech. Category Code $=4)$} \\
\hline $\begin{array}{l}\text { Tech. Sub- } \\
\text { Category }\end{array}$ & $\begin{array}{l}\text { Communi } \\
\text { cations }\end{array}$ & $\begin{array}{c}\text { Computer } \\
\text { Hardware } \\
\& \\
\text { Software }\end{array}$ & $\begin{array}{c}\text { Computer } \\
\text { Peripheral } \\
\text { s }\end{array}$ & $\begin{array}{c}\text { Info. } \\
\text { Storage }\end{array}$ & $\begin{array}{c}\text { Electronic } \\
\text { business } \\
\text { methods } \\
\text { and } \\
\text { software }\end{array}$ & $\begin{array}{c}\text { Electrica } \\
1 \\
\text { Devices }\end{array}$ & $\begin{array}{c}\text { Electrical } \\
\text { Lighting }\end{array}$ & $\begin{array}{c}\text { Measurin } \\
\text { g \& } \\
\text { Testing }\end{array}$ & $\begin{array}{c}\text { Nuclea } \\
\text { r \& X- } \\
\text { rays }\end{array}$ & $\begin{array}{c}\text { Power } \\
\text { System } \\
\text { s }\end{array}$ & $\begin{array}{c}\text { Semico } \\
\text { nductor } \\
\text { Device } \\
\mathrm{s}\end{array}$ & $\begin{array}{c}\text { Miscell } \\
\text { aneous- } \\
\text { Elec. }\end{array}$ & TOTAL \\
\hline $\begin{array}{c}\text { Tech. Sub } \\
\text { Category \# }\end{array}$ & 21 & 22 & 23 & 24 & 25 & 41 & 42 & 43 & 44 & 45 & 46 & 49 & $\begin{array}{c}\text { (Across } \\
\text { Sub. } \\
\text { Cat.) }\end{array}$ \\
\hline Telecom & & & & & & & & & & & & & \\
\hline AT\&T & $\begin{array}{c}124962.9 \\
(4513)\end{array}$ & $\begin{array}{c}25880.42 \\
(995)\end{array}$ & $\begin{array}{c}5619.225 \\
(205)\end{array}$ & $\begin{array}{c}8917.1 \\
(346)\end{array}$ & $\begin{array}{c}5825.99 \\
(131)\end{array}$ & $\begin{array}{c}10360.6 \\
(783)\end{array}$ & $\begin{array}{c}4994.87 \\
(280)\end{array}$ & $\begin{array}{c}3721.37 \\
(283)\end{array}$ & $\begin{array}{c}2856.2 \\
(152)\end{array}$ & $\begin{array}{c}6138.4 \\
(353)\end{array}$ & $\begin{array}{l}18186 \\
(913)\end{array}$ & $\begin{array}{l}5800 \\
(283)\end{array}$ & $\begin{array}{c}223263 \\
(9237)\end{array}$ \\
\hline Bellsouth & $\begin{array}{c}7401.597 \\
(654)\end{array}$ & $\begin{array}{c}872.8536 \\
(113)\end{array}$ & $\begin{array}{c}39.4 \\
(7)\end{array}$ & $\begin{array}{c}385.34 \\
(39)\end{array}$ & $\begin{array}{c}423.2063 \\
\text { (35) }\end{array}$ & $\begin{array}{c}81.6274 \\
(26)\end{array}$ & $\begin{array}{c}0 \\
(2)\end{array}$ & $\begin{array}{c}45.6535 \\
\text { (3) }\end{array}$ & $\begin{array}{c}0 \\
(0)\end{array}$ & $\begin{array}{c}34.872 \\
(11)\end{array}$ & $\begin{array}{c}0 \\
(0)\end{array}$ & $\begin{array}{c}100.49 \\
(11)\end{array}$ & $\begin{array}{c}9385.04 \\
(901)\end{array}$ \\
\hline Qwest & $\begin{array}{c}1638.677 \\
(155)\end{array}$ & $\begin{array}{c}817.2112 \\
(35)\end{array}$ & $\begin{array}{c}26.2683 \\
\text { (1) }\end{array}$ & $\begin{array}{c}103.31 \\
(6)\end{array}$ & $\begin{array}{c}145.1716 \\
(11)\end{array}$ & $\begin{array}{c}38.8284 \\
\text { (3) }\end{array}$ & $\begin{array}{c}0 \\
(0)\end{array}$ & $\begin{array}{c}0 \\
(0)\end{array}$ & $\begin{array}{c}0 \\
(0)\end{array}$ & $\begin{array}{c}22.492 \\
\text { (2) }\end{array}$ & $\begin{array}{c}0 \\
(0)\end{array}$ & $\begin{array}{c}52.437 \\
(4)\end{array}$ & $\begin{array}{c}2844.4 \\
(217)\end{array}$ \\
\hline SBC & $\begin{array}{c}0 \\
(0)\end{array}$ & $\begin{array}{c}0 \\
(0)\end{array}$ & $\begin{array}{c}0 \\
(0)\end{array}$ & $\begin{array}{c}0 \\
(0)\end{array}$ & $\begin{array}{c}0 \\
(0)\end{array}$ & $\begin{array}{c}0 \\
(0)\end{array}$ & $\begin{array}{c}0 \\
(0)\end{array}$ & $\begin{array}{c}0 \\
(0)\end{array}$ & $\begin{array}{c}0 \\
(0)\end{array}$ & $\begin{array}{c}0 \\
(0)\end{array}$ & $\begin{array}{c}0 \\
(0)\end{array}$ & $\begin{array}{c}0 \\
(0)\end{array}$ & $\begin{array}{c}0 \\
(0)\end{array}$ \\
\hline Verizon & $\begin{array}{c}2539.966 \\
(134)\end{array}$ & $\begin{array}{c}790.5595 \\
(44)\end{array}$ & $\begin{array}{c}0 \\
(0)\end{array}$ & $\begin{array}{c}617.78 \\
(30)\end{array}$ & $\begin{array}{c}79.7723 \\
\text { (9) }\end{array}$ & $\begin{array}{c}0 \\
(1)\end{array}$ & $\begin{array}{c}0 \\
(0)\end{array}$ & $\begin{array}{c}8.7795 \\
\text { (2) }\end{array}$ & $\begin{array}{c}0 \\
(0)\end{array}$ & $\begin{array}{c}0 \\
(0)\end{array}$ & $\begin{array}{c}0 \\
(0)\end{array}$ & $\begin{array}{c}40.051 \\
\text { (4) }\end{array}$ & $\begin{array}{c}4076.91 \\
(224)\end{array}$ \\
\hline Cable & & & & & & & & & & & & & \\
\hline Cablevision & $\begin{array}{c}0 \\
(0)\end{array}$ & $\begin{array}{c}0 \\
(0)\end{array}$ & $\begin{array}{c}0 \\
(0)\end{array}$ & $\begin{array}{c}0 \\
(0)\end{array}$ & $\begin{array}{c}0 \\
(0)\end{array}$ & $\begin{array}{c}0 \\
(0)\end{array}$ & $\begin{array}{c}0 \\
(0)\end{array}$ & $\begin{array}{c}0 \\
(0)\end{array}$ & $\begin{array}{c}0 \\
(0)\end{array}$ & $\begin{array}{c}0 \\
(0)\end{array}$ & $\begin{array}{c}0 \\
(0)\end{array}$ & $\begin{array}{c}0 \\
(0)\end{array}$ & $\begin{array}{c}0 \\
(0)\end{array}$ \\
\hline Charter & $\begin{array}{c}0 \\
(0)\end{array}$ & $\begin{array}{c}0 \\
(0)\end{array}$ & $\begin{array}{c}0 \\
(0)\end{array}$ & $\begin{array}{c}0 \\
(0)\end{array}$ & $\begin{array}{c}0 \\
(0)\end{array}$ & $\begin{array}{c}0 \\
(0)\end{array}$ & $\begin{array}{c}0 \\
(0)\end{array}$ & $\begin{array}{c}0 \\
(0)\end{array}$ & $\begin{array}{c}0 \\
(0)\end{array}$ & $\begin{array}{c}0 \\
(0)\end{array}$ & $\begin{array}{c}0 \\
(0)\end{array}$ & $\begin{array}{c}0 \\
(0)\end{array}$ & $\begin{array}{c}0 \\
(0)\end{array}$ \\
\hline Comcast & $\begin{array}{c}96.59 \\
(2)\end{array}$ & $\begin{array}{c}0 \\
(1)\end{array}$ & $\begin{array}{c}0 \\
(0)\end{array}$ & $\begin{array}{c}0 \\
(0)\end{array}$ & $\begin{array}{c}0 \\
(0)\end{array}$ & $\begin{array}{c}0 \\
(0)\end{array}$ & $\begin{array}{c}0 \\
(0)\end{array}$ & $\begin{array}{c}0 \\
(0)\end{array}$ & $\begin{array}{c}0 \\
(0)\end{array}$ & $\begin{array}{c}0 \\
(0)\end{array}$ & $\begin{array}{c}0 \\
(0)\end{array}$ & $\begin{array}{c}0 \\
(0)\end{array}$ & $\begin{array}{c}96.59 \\
(3)\end{array}$ \\
\hline Cox & $\begin{array}{c}0 \\
(0)\end{array}$ & $\begin{array}{c}0 \\
(0)\end{array}$ & $\begin{array}{c}0 \\
(0)\end{array}$ & $\begin{array}{c}0 \\
(0)\end{array}$ & $\begin{array}{c}0 \\
(0)\end{array}$ & $\begin{array}{c}0 \\
(0)\end{array}$ & $\begin{array}{c}0 \\
(0)\end{array}$ & $\begin{array}{c}0 \\
(0)\end{array}$ & $\begin{array}{c}0 \\
(0)\end{array}$ & $\begin{array}{c}0 \\
(0)\end{array}$ & $\begin{array}{c}0 \\
(0)\end{array}$ & $\begin{array}{c}0 \\
(0)\end{array}$ & $\begin{array}{c}0 \\
(0)\end{array}$ \\
\hline $\begin{array}{r}\text { Diva } \\
\text { Sys/TVGate } \\
\text { way }^{1}\end{array}$ & $\begin{array}{c}216.902 \\
(13)\end{array}$ & $\begin{array}{c}374.3791 \\
(11)\end{array}$ & $\begin{array}{c}7.267 \\
(2)\end{array}$ & $\begin{array}{c}72.979 \\
(2)\end{array}$ & $\begin{array}{c}688.7426 \\
(22)\end{array}$ & $\begin{array}{c}0 \\
(0)\end{array}$ & $\begin{array}{c}0 \\
(0)\end{array}$ & $\begin{array}{c}0 \\
(0)\end{array}$ & $\begin{array}{c}0 \\
(0)\end{array}$ & $\begin{array}{c}0 \\
(0)\end{array}$ & $\begin{array}{c}0 \\
(0)\end{array}$ & $\begin{array}{c}3.7487 \\
\text { (1) }\end{array}$ & $\begin{array}{c}1364.02 \\
(51)\end{array}$ \\
\hline Time Warner & $\begin{array}{c}68.3568 \\
(6)\end{array}$ & $\begin{array}{c}307.5549 \\
(14)\end{array}$ & $\begin{array}{c}16.0231 \\
\text { (2) }\end{array}$ & $\begin{array}{c}417.8 \\
(7)\end{array}$ & $\begin{array}{c}810.0141 \\
(17)\end{array}$ & $\begin{array}{c}0 \\
(0)\end{array}$ & $\begin{array}{c}3.7487 \\
\text { (1) }\end{array}$ & $\begin{array}{c}0 \\
(0)\end{array}$ & $\begin{array}{c}0 \\
(0)\end{array}$ & $\begin{array}{c}0 \\
(0)\end{array}$ & $\begin{array}{c}0 \\
(0)\end{array}$ & $\begin{array}{c}561.05 \\
(22)\end{array}$ & $\begin{array}{c}2184.55 \\
(69)\end{array}$ \\
\hline
\end{tabular}

1 - Diva Systems/ TVGateway is a joint venture between Charter, Comcast and Cox 
TABLE 9 - Results of Event study measuring abnormal stock market returns for announcements related to firms' convergent strategies

\begin{tabular}{|c|c|c|c|c|c|}
\hline \multirow[t]{2}{*}{$\begin{array}{l}\text { Days over which } \\
\text { Abnormal returns } \\
\text { were calculated }\end{array}$} & \multirow[t]{2}{*}{$\begin{array}{l}\text { Number } \\
\text { of } \\
\text { Events }\end{array}$} & \multicolumn{2}{|c|}{$\begin{array}{l}\text { Average market adjusted } \\
\text { abnormal returns (equally } \\
\text { weighted market index) }\end{array}$} & \multicolumn{2}{|c|}{ Significance tests } \\
\hline & & $\begin{array}{c}\text { Mean } \\
\text { Cumulative } \\
\text { Abnormal } \\
\text { Return } \\
\text { (CAAR) }\end{array}$ & $\begin{array}{c}\text { Precision } \\
\text { weighted CAAR }\end{array}$ & $\begin{array}{c}\text { Patell ' } Z \text { ' test (Z- } \\
\text { Value) }\end{array}$ & $\begin{array}{c}\text { Generalized } \\
\text { Sign 'Z' test } \\
\text { (Z-value) }\end{array}$ \\
\hline \multicolumn{6}{|l|}{ Telecom Firms } \\
\hline 1 day $(-1,0)$ & 17 & $-0.56 \%$ & $-0.63 \%$ & $-1.595^{*}$ & -1.004 \\
\hline 2 days $(-1,+1)$ & 17 & $-0.48 \%$ & $-0.57 \%$ & -1.174 & $-1.489 *$ \\
\hline 3 days $(-1,+2)$ & 17 & $-0.80 \%$ & $-0.88 \%$ & $-1.572 *$ & $-1.975 * *$ \\
\hline 1 week $(-1,+7)$ & 17 & $-2.13 \%$ & $-2.25 \%$ & $-2.686 * * *$ & $-1.489 *$ \\
\hline \multicolumn{6}{|l|}{ Cable firms } \\
\hline 1 day $(-1,0)$ & 18 & $1.25 \%$ & $2.12 \%$ & $2.576^{* * * *}$ & $1.354 *$ \\
\hline 2 days $(-1,+1)$ & 18 & $0.98 \%$ & $1.72 \%$ & $1.705 * *$ & $1.354 *$ \\
\hline 3 days $(-1,+2)$ & 18 & $1.21 \%$ & $1.76 \%$ & $1.514 *$ & $1.354 *$ \\
\hline 1 week $(-1,+7)$ & 18 & $1.26 \%$ & $2.09 \%$ & 1.198 & $1.828^{*}$ \\
\hline
\end{tabular}

The symbols $*$, **, and $* * *$ denote statistical significance at the $0.10,0.05$ and 0.01 levels Abnormal market returns and significance tests calculated using EVENTUS 